2012

\title{
Preventing Sex-Offender Recidivism Through Therapeutic Jurisprudence Approaches and Specialized Community Integration
}

Heather Cucolo

Michael L. Perlin

New YorkLaw School, michael.perlin@nyls.edu

Follow this and additional works at: http://digitalcommons.nyls.edu/fac_articles_chapters

Part of the Criminal Procedure Commons, Disability Law Commons, Law and Psychology Commons, and the Medical Jurisprudence Commons

\section{Recommended Citation}

22 Temp. Pol. \& Civ. Rts. L. Rev. 1 (2012-2013)

This Article is brought to you for free and open access by the Faculty Scholarship at DigitalCommons@NYLS. It has been accepted for inclusion in Articles \& Chapters by an authorized administrator of DigitalCommons@NYLS. 


\title{
PREVENTING SEX-OFFENDER RECIDIVISM THROUGH THERAPEUTIC JURISPRUDENCE APPROACHES AND SPECIALIZED COMMUNITY INTEGRATION
}

\author{
by HeAther ElLis CuColo* \\ MiCHAEL L. PERLIN ${ }^{* *}$
}

\begin{abstract}
'The public's panic about the fear of recidivism if adjudicated sex offenders are ever to be released to the community has not subsided, despite the growing amount of information and statistically-reliable data signifying a generally low risk of re-offense. The established case law upholding sexoffender civil commitment and containment statutes has generally rejected challenges of unconstitutionality, and continues to be dominated by punitive undertones. We have come to learn that the tools used to assess offenders for risk and civil commitment still have indeterminate accuracy, and that meaningful treatment for this population remains uncertain in its availability and debatable as to its effectiveness. Yet, society continues to clamor for legislation confining this cohort of offenders for treatment, and, ostensibly, protection of the community. Legislatures tend to respond quickly to these calls. This reform legislation often includes strict and demeaning post-release restrictions that track offenders and undermine their integration into society. These reforms continue to show no benefit either to the public or to the individual offender. The absence of meaningful and effective treatment during confinement, combined with inhumane conditions upon release, make it far less likely that this cohort of individuals will ever become productive members of society. Only through therapeutic jurisprudence, a focus on rehabilitation, and the humane treatment of individuals who have committed sexual offenses will it be possible to reduce recidivism and facilitate successful community reintegration.

This article takes a new approach to these issues. It examines sexoffender laws past and present, looks at sex-offender commitment and containment through a therapeutic jurisprudence lens, and suggests basic policy changes that would optimally and constitutionally minimize re-

\footnotetext{
* Adjunct Professor of Law, New York Law School; J.D., New York Law School; B.A., SUNY Binghamton.

** Professor of Law, New York Law School; J.D., Columbia University School of Law; A.B.,

I. Portions of this paper were presented at the Academy of Criminal Justice Sciences annual conference, New York City, March 2012.
} Rutgers University,
\end{abstract}


offense rates, while upholding and protecting the rights of all citizens. This article highlights the failure of community containment laws and ordinances by focusing on (1) the myths and perceptions that have arisen about sex offenders, and how society codifies those myths in legislation, (2) the lack of rehabilitation offered to incarcerated or civilly committed offenders, which results in inadequate re-entry preparation, (3) the anti-therapeutic and inhumane effect of the laws and ordinances created to restrict sex offenders in the community, and (4) the reluctance and resistance of courts to incorporate therapeutic jurisprudence in seeking to remediate this set of circumstances. It concludes by offering some modest suggestions, based on the adoption of a therapeutic jurisprudence model of analysis.

\section{INTRODUCTION}

Individuals who have committed sex offenses have taken center stage in both the criminal and civil legal systems. ${ }^{2}$ Currently, no other population is more despised, more vilified, more subject to media misrepresentation, ${ }^{3}$ and more likely to be denied basic human rights. ${ }^{4}$ Endless emotionally charged debates have ensued, focusing on how to ostensibly maintain safety in local communities while containing the "sexual predator." Unfortunately, most of these debates are premised upon incorrect facts and spurious data that have been distorted and skewed to support political agendas that respond to-or perhaps in some cases, incite-community outcries for retribution. ${ }^{6}$

2. See Corey Rayburn Yung, The Emerging Criminal War on Sex Offenders, 45 HARV. C.R.-C.L. L. REV. 435, 436-38 (2010) (discussing the current political emphasis on punishing sex offenders).

3. E.g., Chris Greer, News Media, Victims and Crime, in VICTIMS, CRIME AND SOCIETY 20, 40-41 (Pamela Davies, Peter Francis \& Chris Greer eds., 2007) (discussing sensationalization of sex crimes in the media).

4. See Hollida Wakefield, The Vilification of Sex Offenders: Do Laws Targeting Sex Offenders Increase Recidivism and Sexual Violence?, 1 J. SEXUAL OFFENDER CIV. COMMITMENT: SCI. \& L. 141, 141-49 (2006), available at http://ccoso.org/Vilification.pdf (examining the potential harmful effects of the current policies regarding sex offenders and emphasizing the lack of evidentiary support for these policies). See Adam Deming, Sex Offender Civil Commitment Programs: Current Practices, Characteristics, and Resident Demographics, 36 J. PSYCHIATRY \& L. 439, 440 (2008) (noting that typical civil commitment schemes are found to violate civil rights, but when applied to sex offenders, these statutes are typically upheld).

5. Public outcry has led to a continual increase in restrictions on sex offenders who are out of custody, despite a lack of evidence that these laws are effective. See lan Lovett, Public-Place Laws Tighten Rein on Sex Offenders, N.Y. TIMES, May 29, 2012, http://www.nytimes.com/2012/05/30/us/sexoffenders-face-growing-restrictions-on-public-places.html (explaining that sex offenders are banned from public parks in Orange County, Cal.); Abby Sewell, Halloween Night Restrictions are Added for Sex Offenders, L.A. TIMES, Nov. 1, 2011, http://articles.latimes.com/2011/nov/01/local/la-mehalloween-offenders-20111101 (explaining that sex offenders are subjected to restrictions on Halloween celebrations in Los Angeles, Cal.); Megan Twohey, Sex Offender Housing Restrictions May Lead to More Crimes, CHI. TRIB., Apr. 9, 2010, http://articles.chicagotribune.com/2010-04-09/news/ct-met-sexoffender-housing-20100408_1_offenders-parole-housing-restrictions (explaining that housing restrictions for sex offenders in Chicago, Ill. may in fact place the public at a greater risk).

6. See Michelle Meloy et al., Sex Offender Laws in America: Can Panic-Driven Legislation Ever Create Safer Societies?, 20 CRIM. JUST. STUD. 423, 424-28 (2007) (discussing state and federal 
State and federal legislators have addressed society's fear and outrage by enacting statutes that keep such offenders locked up indefinitely.? If there is to be eventual release, such offenders are subjected to strict monitoring upon return to the community. ${ }^{8}$ Sex-offender civil commitment and community containment laws were developed as reactionary responses to the widely feared but statistically rare, violent, child-directed and stranger-perpetrated sex crime.?

Under the prevailing statutory schemes 10 -many of which have been patterned after the statute upheld by the United States Supreme Court in Kansas v. Hendricks" 1 -individuals who have committed sexual offenses or certain qualifying offenses deemed to have a sexual component ${ }^{12}$ may be

responses to the sex offender panic and noting that many of the most popular methods of dealing with sex offenders-community notification and civil commitment-are not evidence-based responses to the problem and have yet to be proven effective).

7. E.g., Call v. Gomez, 535 N.W.2d 312, 319 (Minn. 1995) (noting that continued confinement of a person committed as a "psychopathic personality" under a Minnesota statute is justified if the confinement bears a reasonable relation to the original reason for commitment).

8. E.g., WASH. REV. CODE ANN. $\$ 71.09 .096$ (West 2009) (providing that, upon release from civil commitment, persons may be subjected to residency restrictions, prohibition of alcohol and drug use, and extensive monitoring that may include a satellite-based navigation system incorporating a global positioning system (GPS)).

9. See Kevin M. Carlsmith et al., The Function of Punishment in the "Civil" Commitment of Sexually Violent Predators, 25 BEHAV. SCI. \& L. 437, 445-47 (2007) (considering the retributive motivations for sexually violent predator ("SVP") commitment); see also Leonore M. J. Simon, Matching Legal Policies with Known Offenders, in Protecting SOCIETY From SEXUALLy DaNGEROUS OfFEnders: LAW, Justice, \& THERAPY 149, 149 (Bruce J. Winick \& John Q. La Fond eds., 2003) [hereinafter PROTECTING SOCIETY] (citations omitted) ("Legal policies targeting sex offenders are appearing in an increasing number of states and on the federal level. These policies often result from widely publicized heinous sex crimes committed by stranger offenders. Washington State, for example, enacted its community notification legislation after a 7 -year-old boy was raped and mutilated by a convicted sex offender. ... [T] he resulting legislation was designed to protect children from strangers. Such legislation, however, promotes 'a false sense of security, lulling parents and children into the bigbad-man mindset when many molesters are in fact trusted authority figures or family members."').

10. E.g., Kan. Stat. ANN. $\$ 59-29$ a et seq. (2009); WaSh. Rev. Code AnN. $\$ 71.09$ et seq. (West 2009); see also Wanda D. Beyer Kendall \& Monit Cheung, Sexually Violent Predators And Civil Commitment Laws, 13 J. ChILD SeXUAL ABUSE 41, 48-52 (2008) (noting that sixteen states have involuntary civil commitment laws that provide for continuous confinement of SVPs).

11. 521 U.S. 346 (1997) (upholding Kansas' Sexually Violent Predator Act).

12. E.g., WASH. REV. CODE ANN. $§ 71.09 .020$ (15) (West 2009) (“'Sexually violent offense' means an act committed on, before, or after July 1, 1990, that is: (a) An act defined in Title 9A RCW as rape in the first degree, rape in the second degree by forcible compulsion, rape of a child in the first or second degree, statutory rape in the first or second degree, indecent liberties by forcible compulsion, indecent liberties against a child under age fourteen, incest against a child under age fourteen, or child molestation in the first or second degree; (b) a felony offense in effect at any time prior to July 1, 1990, that is comparable to a sexually violent offense as defined in (a) this subsection, or any federal or out-ofstate conviction for a felony offense that under the laws of this state would be a sexually violent offense as defined in this subsection; (c) an act of murder in the first or second degree, assault in the first or second degree, assault of a child in the first or second degree, kidnapping in the first or second degree, burglary in the first degree, residential burglary, or unlawful imprisonment, which act, either at the time of sentencing for the offense or subsequently during civil commitment proceedings pursuant to this chapter, has been determined beyond a reasonable doubt to have been sexually motivated, as that term is defined in RCW 9.94A.030; or (d) an act as described in chapter 9A.28 RCW, that is an attempt, criminal solicitation, or criminal conspiracy to commit one of the felonies designated in (a), (b), or (c) of 
civilly committed for care and "treatment" at the conclusion of their prison sentence. ${ }^{13}$ Such a civil commitment, although originally intended to apply only to the most heinous and dangerous offenders, has become a widelyused tool, designed to contain large numbers of offenders whether or not their sexually motivated crimes were severe or frequent. ${ }^{14}$ Only and if the risk to re-offend is perceived to be sufficiently reduced, are committed offenders considered for release back into the community. ${ }^{15}$ Upon release, individuals are subjected to community containment laws that impose strict conditions on place of residence, type of employment, and freedom of movement, which often include intensive and intrusive monitoring. ${ }^{16}$ The state and federal governments' enactment of registration and notification statutes has widened the net over vast numbers of individuals who have committed a wide range of offenses, sexually-motivated or otherwise. ${ }^{17}$

this subsection.").

13. E.g., KAN. STAT. ANN. $§ 59-29 \mathrm{a} 01$ (providing for post-prison civil commitment of SVPs).

For a discussion on effective (and ineffective) methods of treatment for sex offenders and sexual predators, see Bruce J. Winick, Sex Offender Law in the 1990s: A Therapeutic Jurisprudence Analysis, 4 PSYCHOL. PUB. POL'Y. \& L. 505 (1998) (discussing effective and ineffective methods of treatment for sex offenders and sexual predators).

14. This broad application flies in the face of the Supreme Court's mandate in upholding these statutes, noting that they only apply to a narrow class of individuals. Hendricks, 521 U.S. at 364; see, e.g., OfFice of THE Legislative Auditor: State of Minn., Civil COMMitMENT of SEX OffEnders (Mar. 2011), available at http:/www.auditor.leg.state.mn.us/ped/2011/ccsosum.htm ("The number of civilly committed sex offenders in the Minnesota Sex Offender Program (MSOP) nearly quadrupled during the last decade and is expected to nearly double over the next ten years."); see also W. VA. SeXually Violent Predator Mgmt. TASK ForCe, Final RePORT, 9 (2007), available at http://www.wvpds.org/SVP\%20report-\%20Final\%20-6-30-2007.pdf [hereinafter WEST VIRGINIA REPORT] ("The qualifying offense feature of the definition is narrow in scope, creating gaps for high risk offenders to slip past. On the other hand, the mental abnormality component of the definition is too broad in scope, allowing inappropriate offenders to be chameled through the screening process.").

15. E.g., WASH. REV. CODE ANN $\$ 71,09.090$ (West 2009) ("(1) If the secretary determines that the person's condition has so changed that either: (a) The person no longer meets the definition of a sexually violent predator; or (b) conditional release to a less restrictive alternative is in the best interest of the person and conditions can be imposed that adequately protect the community, the secretary shall authorize the person to petition the court for conditional release to a less restrictive alternative or unconditional discharge."). But see, e.g., In re Senty-Haugen, 583 N.W.2d 266, 268 (Minn. 1998) (" $[U]$ nlike commitment procedures for persons with mental illness, mental retardation or chemical dependency, Minn. Stat. $\S 253$ B.185, governing SPP/SDP commitments, simply does not require that such commitments be made to the least restrictive treatment program.").

16. See, e.g., WASH. REv. CODE ANN $\$ 71.09 .096$ (West 2009) ("(4) Prior to authorizing any release to a less restrictive alternative, the court shall impose such conditions upon the person as are necessary to ensure the safety of the community. The court shall order the department of corrections to investigate the less restrictive alternative and recommend any additional conditions to the court. These conditions shall include, but are not limited to the following: Specification of residence, prohibition of contact with potential or past victims, prohibition of alcohol and other drug use, participation in a specific course of inpatient or outpatient treatment that may include monitoring by the use of polygraph and plethysmograph, monitoring through the use of global positioning satellite technology, supervision by a department of corrections community corrections officer, a requirement that the person remain within the state unless the person receives prior authorization by the court, and any other conditions that the court determines are in the best interest of the person or others. A copy of the conditions of release shall be given to the person and to any designated service providers.").

17. See, e.g., State v. Smith, 780 N.W.2d 90, 105-06 (Wis. 2010) (finding that a seventeen-year-old 
Ironically and sadly, it has been empirically shown that these laws do little to protect the public. ${ }^{18}$ Instead, they have been proven to ostracize, isolate, and destroy any hope of re-integration for convicted sex offenders; these laws may even tend to increase recidivism. ${ }^{19}$ Many are beginning to wonder whether the increasing costs of enforcing these laws are justifiable. ${ }^{20}$

This paper intends to highlight the failure of community containment laws and ordinances by focusing on (1) the myths and perceptions of sex offenders and how society incorporates those myths into legislation, (2) the lack of rehabilitation offered to incarcerated or civilly committed offenders which results in inadequate re-entry preparation, (3) the anti-therapeutic and inhumane effect of the laws and ordinances created to restrict sex offenders in the community, and (4) the reluctance and resistance of courts to incorporate therapeutic jurisprudence in seeking to remediate this set of circumstances. We will conclude by offering some modest suggestions, based on the adoption of a therapeutic jurisprudence model of analysis.

The absence of meaningful and effective treatment during confinement combined with inhumane conditions upon release make it far less likely that this cohort of individuals will ever become productive members of society. Only through therapeutic jurisprudence, focus on rehabilitation, and humane treatment of individuals who have committed sexual offenses will it be possible to reduce recidivism and foster successful community reintegration.

\section{Perceptions of a SeX Offender Epidemic}

$[\mathrm{N}]$ othing is more threatening to our families and communities and more destructive of our basic values than sex offenders who victimize children and families. Study after study tell us that they often repeat the same crimes. That's why we have to stop sex offenders before they commit their next crime, to make our children safe and give their parents peace of mind. ${ }^{21}$

male convicted as a sex offender based on the crime of false imprisonment during a drug exchange was sanctioned for failing to update the State with personal information). Under a rational basis standard, the sex-offender registration statute was upheld as constitutional, though it required persons convicted of non-sex crimes to register. Id:; see also Melissa Wangenheim, "To Catch a Predator," Are We Casting Our Nets Too Far?: Constitutional Concerns Regarding the Civil Commitment of Sex Offenders, 62 RUTGERS L. REV. 559, 592-97 (2010)(evaluating the over-inclusiveness of civil commitment practices and their tenacious classification as within constitutional bounds).

18. See Kristen Zgoba et al., MEGAN's LAW: ASSESSING THE PRACTICAL AND MONETARY EFFICACY 41, available at https://www.ncjrs.gov/pdffiles 1/nij/grants/225370.pdf (examining efficacy of Megan's Law in New Jersey and finding no reduction in re-offense rates or in the number of victims between ten years before and ten years after the law was enacted, thus unable to determine whether the law affects recidivism, harm reduction, or community tenure).

19. See Wakefield, supra note 4 , at 141-49 (examining the potential harmful effects of the current policies regarding sex offenders).

20. See Zgoba, supra note 18 , at 39 (explaining that the costs associated with implementing Megan's Law are growing and noting that implementation costs across the state increased from $\$ 555,565$ in 1994 to $\$ 3.9$ million in 2007).

21. William J. Clinton, The President's Radio Address (Aug. 24, 1996) (transcript available at 
Political pressure is only one of the many reasons why focus on this area of the law has expanded substantially. ${ }^{22}$ Some of the other most salient reasons include:

- media-driven frenzies over rare yet horrific acts of sexual violence against children;23

- an unsubstantiated belief that future recidivism is high and most sex offenders will re-offend, ${ }^{24}$ a belief that is reinforced by popular media depictions ${ }^{25}$ (such as those on the popular TV show, Law and Order: Special Victims Unit); ${ }^{26}$

- the constraints in prosecuting sex crimes and the public's frustration with plea bargains carrying light sentences for these specific types of offenses; ${ }^{27}$

http://www.presidency.ucsb.edu/ws/index.php?pid=53230) (referring to community notification laws as a way to give "parents and police . . the warning they need to protect children.").

22. See Eric S. Janus, Closing Pandora's Box: Sexual Predators and the Politics of Sexual Violence, 34 SeTON Hall L. REV. 1233, 1233-50 (2004) (discussing how the effect of politics and public outcry fuels the expansion of sexually violent predator programs). See generally Roxanne Lieb et al., Sexual Predators and Social Policy, 23 CRIME \& JUST. 43 (1998) (evaluating social policies regarding sexual predators and calling for an increased focus on empirical research in the development of such policies).

23. See Michael H. Miner, Editorial: Is This Any Way to Develop Policy?, 2 SEXUAL Offender TREATMENT (2007), http://www.sexual-offender-treatment.org/54.html (discussing the link between isolated incidents of horrific child sexual abuse and enactment of more restrictive sex offender laws). It must be noted that within the last few years there has been a shift in the media's presentation of sexual crimes and legislative responses. The state of the economy (raising concerns about the exorbitant cost of sex offender facilities) coupled with high profile cases involving otherwise respected members of the community seem to have opened a wider dialogue in analyzing these issues with focus on the legality of these laws and the reality of sex offender re-offense and risk. See, e.g., Erica Goode, Researchers See Decline in Child Sexual Abuse Rate, N.Y. TIMES, June 29, 2012, http:/www.nytimes.com/2012/06/29/us/rate-of-child-sexual-abuse-on-the-decline.html (standing for the proposition that sexual abuse is increasingly rare); Monica Davey \& Abby Goodnough, Doubts Rise as States Hold Sex Offenders After Prison, N.Y. Times, Mar. 4, 2007, http://www.nytimes.com/2007/03/04/us/04civil.html (voicing concerns about the current trend of increased civil commitments and lack of evidentiary support for the effectiveness of this method of dealing with sex offenders).

24. Charles H. Rose III, Caging the Beast: Formulating Effective Evidentiary Rules to Deal with Sexual Offenders, 34 AM. J. CRIM. L. 1, 21 (2006) (providing empirical data that shows sex offenders are less likely to commit the same category of offense when recidivating than other categories of offenders).

25. See, e.g., Amy Adler, To Catch a Predator, 21 Colum. J. Gender \& L. 130, $137-45$ (2011) (analyzing the TV program "To Catch a Predator" and its effect on public policy).

26. Hal Arkowitz \& Scott O. Lilienfeld, Once a Sex Offender, Always a Sex Offender? Maybe Not, SCIENTIFIC AMERICAN (Apr. http:/www.scientificamerican.com/article.cfm?id=misunderstood-crimes ("[T] the general public believes that 75 percent of sex offenders will reoffend. This perception is consistent with media portrayals in such television programs as Law and Order: Special Victims Unit, in which sex offenders are almost always portrayed as chronic repeaters.").

27. See Hendricks, 521 U.S. at 373 (Kennedy, J. concurring) ("If the civil system is used simply to impose punishment after the State makes an improvident plea bargain on the criminal side, then it is not performing its proper function."); Jenny Roberts, The Mythical Divide Between Collateral and Direct Consequences of Criminal Convictions: Involuntary Commitment of "Sextially Violent Predators" 93 MIN. L. REV. 670, 682-83 (2008) (describing the practical incentives that may lead a sex offender to 
- the drastic increase in the availability of psychiatric and psychological expert testimony supporting prosecutorial applications for extended incarceration post-sentence; ${ }^{28}$

- the creation of numerous employment opportunities for psychologists and social workers within the civil commitment institutions for persons committed under "Sexually Violent Predator" (SVP) laws, ${ }^{29}$ and

- the loosely defined SVP statutory requirements that result in misapplication of the intent of the law and arbitrary decisions as to which offenders and what behavior warrants civil commitment. ${ }^{30}$

The programmatic goal of SVP laws was to focus society's attention on those offenders who pose the greatest risk and likelihood of recidivism. However, information regarding "who" fit the profile of the goal-directed group was uncertain and inconclusive at the time the laws were initially enacted. ${ }^{31}$ In fact, valid and reliable evidence tells us that incest and familial offenses are the most common occurrences of sexual violence. ${ }^{32}$ Without

choose to enter into a plea bargain in order to avoid the harsh collateral consequences of conviction at trial); see also Carlsmith et al., supra note 9, at 445-46 (detailing a controlled study that found that when the criminal sentence was lenient, respondents strongly supported civil commitment without regard to future risk); Eric Hartley, Molesters Getting a Slap on the Wrist? Lack of Jail Time in Cases Sparks Sentencing Debate, THE CAPITAL, Apr. 22, 2007, at All (discussing public criticism of perceived lenient sentences for child molesters).

28. See Christine Willmsen, State Wastes Millions Helping Sex Predators Avoid Lockup, SEATTLE TIMES, Jan. 21, 2012, http://seattletimes.com/html/localnews/2017301107_civilcomm22.html (emphasizing the high cost of maintaining Washington's civil commitment program, much of which goes to forensic psychologists who evaluate sex offenders and testify throughout the state regularly); see also Gary Craig, Expert Opinion Among Civil Commitment's High Costs, DemOCRAT \& CHRON. (N.Y.), Dec. 29,2010 ,

http://www.democratandchronicle.com/article/20101229/NEWS01/12290345 (reporting how a psychologist earned approximately $\$ 1$ million over a three-year period from giving expert testimony in sex offender civil commitment cases from Massachusetts and New York).

29. See Gary Craig, Civil Confinement of Sex Offenders Costs State \$175,000 Apiece, DEMOCRAT \& Chron. (N.Y.), Dec. 26,2010,

http://www.democratandchronicle.com/article/20101226/NEWS01/1226031 1/Civil-confinement-ofsexoffenders-costs-state-\$175-000-apiece (discussing New York civil commitment costs: "At the current rate of growth-about 70 newly confined offenders annually-treatment costs alone will grow by about $\$ 12$ million a year.").

30. See John Q. La Fond \& Bruce J. Winick, Op-Ed, Doing More Than Their Time, N.Y. TIMES, May 2l, 2006, http://www.nytimes.com/2006/05/21/opinion/nyregionopinions/21L/lafond.htm (explaining how vague and expansive definitions of civil commitment statutes allow for the confinement of sex offenders who are not mentally disturbed or dangerous).

31. See Karol Lucken \& William Bales, Florida's Sexually Violent Predator Program: An Examination of Risk and Civil Commitment Eligibility, 54 CRIME \& DELINQ. 95, 98 (2008) (discussing the limited amount of empirical data available regarding SOCC risk assessment).

32. SeeLori Presser \& Elaine Gunnison, Strange Bedfellows: Is Sex Offender Notification a Form of Community Justice?, 45 CRIME \& DELINQ. 299, 304 (1999) (citations omitted) ("[I]n nearly 75 percent of sexual assault and rape cases and in 90 percent of those involving children, the victim knew the offender. Forty-three percent of victims under age twelve were assaulted by family members.'); Bruce J. Winick, A Therapeutic Jurisprudence Analysis of Sex Offender Registration and Community Notification Laws, in Protecting Society, supra note 9, at 213, 218 (suggesting that more than seventy-five percent of reported cases of sexual abuse are perpetrated by someone that the child knows). 
significant consideration of sex offender prevalence and dynamics, laws were, based off of the "stranger rapist/murderer" profile and upheld with heavy reliance on expert opinions supporting empirical, then-current "risk determinative" instruments and controversial science. ${ }^{33}$ The studies and

33. For an overview of the discrepancies in risk assessment, see R. Karl Hanson, Who is Dangerous and When are They Safe? Risk Assessment with Sexual Offenders, in Protecting SoCIETY, supra note9, at 63-72. See, e.g., Matter of Registrant G.B., 685 A.2d 1252, 1265-66 (N.J. 1996) (allowing a registrant to introduce expert evidence regarding tier classification under certain circumstances); Matter of Registrant C.A., 679 A.2d 1153, 1170-71 (N.J. 1996) (affirming the reliability of the Registrant Risk Assessment Scale). In In re Commitment of R.S., 801 A.2d 219 (N.J. 2002), the New Jersey Supreme Court stated:

Although there are critics who challenge the validity and predictability of actuarial instruments in sex offender assessments, the record expert testimony and scientific literature demonstrates that clinicians specializing in sex offender assessments generally support the use of actuarial instruments in the overall assessment process even though they do not support reliance on the actuarial instruments alone. . . As the Appellate Division summarized:

The extensive expert testimony in this matter concerning validation studies, crossvalidation studies, reliability studies, correlation coefficients, and clinically-derived factors attests to such reliability in this context, where the actuarials are not used as the sole or free-standing determinants for civil commitment. They are not litmus tests. There is no requirement that the actuarial instruments be the best methods which could ever be devised to determine risk of recidivism. What is required is that they produce results which are reasonably reliable for their intended purpose.

Id. 220-21 (citations omitted) (quoting In re Commitment of R.S., 773 A.2d 72, 91 (N.J. Super. App. Div. 2001).

See also, e.g., State ex rel. Romley v. Fields, 35 P.3d 82, 89 (Ariz. 2001) (concluding the Frye expert test does not apply to actuarial models developed by mental health experts to predict likelihood of recidivism); People v. Therrian, 6 Cal.Rptr.3d 415, 419-20 (Ct. App. 2003) (holding a Kelly hearing regarding admissibility of expert testimony concerning defendant's likelihood of reoffending was unnecessary since testimony was not solely based on the Static-99 test); Roeling v. State, 880 So.2d 1234, 1238-40 (Fla. Dist. Ct. App.2004) (holding that expert opinion testimony satisfied the Frye test); In re Detention of Holtz, 653 N.W.2d 613, 619 (lowa Ct. App.2002) (finding that evidence regarding actuarial risk assessment instruments goes to the weight of evidence and is not an issue of admissibility); In re Care \& Treatment of Teer, No. 89,652, 90 P.3d 379, slip op. at 3-4 (Kan. Ct. App.2004) (unpublished order) (finding that expert testimony concerning risk assessment tests was sufficient evidence for jury to determine offender was a sexually violent predator); Commonwealth v. Wright, No. 032449A, 2004 WL 1690388, at * (Mass. Jul. 15, 2004) (stating that expert testimony established defendant was a sexually dangerous person); In re Risk Level Determination of R.B.P., 640 N.W.2d 351, 353-57 (Minn. Ct. App.2002) (holding that based on special concerns, the End of Confinement Review Committee has the discretion to raise an offender's risk assessment level higher than the results from the Sex Offender Screening Tool indicate); Goddard v. State, 144 S.W.3d 848, 851-55 (Mo. Ct. App.2004) (finding that expert testimony regarding the use of actuarial instruments was admissible); State v. Legg, 84 P.3d 648, 653-54 (Mont. 2004) (finding the court properly considered the contents of a pre-sentencing report, as well as other facts, in determining offender's risk level to victims and community during sentencing); Slansky v. Nebraska State Patrol, 685 N.W.2d 335, 345-49 (Neb. 2004) (stating that risk assessment instrument is a rationally based tool to predict recidivism); People v. Girup, 780 N.Y.S.2d 698, 699 (N.Y. App. Div. 2004) (mem. op.) (stating that the County Court may exercise its discretion and depart from the recommendation of the Board to determine a sex offender's risk level based on the record); In re D.V.A., 676 N.W.2d 776, 778-80 (N.D.2004) (holding that the trial court did not err by admitting psychologist testimony based on risk assessment tests to determine SDP status because psychologists generally rely on these evaluations); State v. McKinniss, 795 N.E.2d 160, 165-67 (Ohio Ct. App. 2003) (review of entire record, not solely the outcomes of psychological tests, resulted in determination of the likelihood of future sex offenses); State v. Gibson, 66 P.3d 560, 564-68 (Or. Ct. 
statistics regarding risk of offender recidivism yielded inaccurate results when applied to individual offenders being evaluated for the likelihood of future re-offenses. ${ }^{34}$

These underlying tools that support confinement and containment continue to be flawed, ${ }^{35}$ and experts drastically disagree on offender statistics and the reliability of actuarial instruments designed to show recidivism. ${ }^{36}$ Despite this, there has been absolutely no movement towards serious modification or repeal of any of these laws, even as studies are reworked and results of earlier studies are re-evaluated, leading to the concomitant rejection of these methods by the same scholars and researchers responsible for pioneering the early studies and statistical

App. 2003) (finding that the existence of a mental disorder that created sufficiently impaired impulse control was enough to conclude appellant was a "dangerous by typical recidivist" sex offender); In re Care \& Treatment of Tucker, 578 S.E.2d 719, $721-22$ (S.C. 2003) (holding that a sex offender failed to show sufficient change in his mental condition so as to warrant release); In re Commitment of Morales, 98 S.W.3d 288, 290-9l (Tex.Ct.App.2003) (finding that a serious difficulty in controlling behavior was established by evidence from psychological tests as well as facts of case, including committing a second sexual offense while on probation for the first and history of heavy drug use with impulsivity issues); In re Detention of Thorell, 72 P.3d 708, 724-26 (Wash. 2003) (upholding the use of actuarial risk assessment instruments in determining future dangerousness of sexual offenders); In re Commitment of Tainter, 655 N.W.2d 538, 543-44 (Wis. 2002) (affirming the trial court's admittance of testimony regarding actuarial instruments).

34. See Robin J. Wilson et al., Comparing Sexual Offenders at the Regional Treatment Centre (Ontario) and the Florida Civil Commitment Center, INT'L J. OfFEndER THERAPY \& COMP. CRIMINOLOGY, 12-16 (2012), available at http://ijo.sagepub.com/content/early/2012/01/17/0306624X11434918 (finding that populations designated as high risk future sexual offenders, upon release, had only between a three and ten percent chance of re-offending); see also Karen Franklin, Treatment and Risk Among the Most Dangerous Sexual Offenders, FORENSIC PSYCHOLOGIST, (Feb. 21, 2012), http://forensicpsychologist.blogspot.com/2012/02/treatment-and-risk-among-most-dangerous.html (discussing the above study).

35. See John Matthew Fabian, The Risky Business of Conducting Risk Assessments for Those Already Civilly Committed as Sexually Violent Predators, 32 WM. MITCHELL L. REV. 81, 85-87 (2005) (describing "the problems and pitfalls" related to sex offender civil commitment reexamination procedures).

36. See, e.g., Wayne A. Logan, A Study in "Actuarial Justice:" Sex Offender Classification Practice and Procedure, 3 BUFF. CRIM. L. REV. 593, 606-19 (2000) (illustrating the different methods used by various states to make discretionary risk assessments of sexual offenders made by courts, executive agencies, prosecutors, judges and/or hybrid combinations of these cohorts); Larry Oakes, They're All Close Calls Now, STAR. TRIB. (Minn.), June 9, 2008, http://www.startribune.com/local/19645554.html (quoting psychiatrist John Austin who stated that risk assessment models "are about 70 percent accurate; thus they're wrong 30 percent of the time"); Eric S. Janus \& Robert A. Prentky, The Forensic Use of Actuarial Risk Assessment with Sex Offenders: Accuracy, Admissibility and Accountability, 40 AM. CRIM. L. REv. 1443, 1486 (2003) (discussing the superiority of actuarial risk assessments which have been tested extensively and have broad acceptance in literature concerning sexual offending); PAUL Meehl, Clinical Versus Statistical Prediction: A Theoretical analysis and a Review of THE EVIDENCE 94-95 (1954) (describing a study which potentially shows actuarial superiority in predicting criminal recidivism); Robert Prentky et al., Sexually Violent Predators in the Courtroom: Science on Trial, 12 PSYCHOL. PUB. POL'Y \& L. 357, 361 (2006) (citing twin concerns that "good science" will be unrecognized or misunderstood by the law, and that the pressures of the law will not only use but encourage "bad science"); Cailey Miller et al., Reliability of Risk Assessment Measures Used in Sexually Violent Predator Proceedings, PSYCHOL. ASSESSMENT, May 7, 2012, at 4-6 (reviewing the reliability of several assessment instruments used in SVP evaluations). 
instruments. ${ }^{37}$

Contemporaneous sex offender civil commitment legislation could not have developed as it did were it not linked securely to the scientific community's findings, especially since such laws were constitutionally upheld as civil acts premised on general civil commitment laws that were already found to be constitutional. ${ }^{38}$ But we must honestly and thoroughly investigate the reasons supporting the enactment of such legislation while scrutinizing legislative usage of medical and scientific testimony to support sex-offender commitments. ${ }^{39}$ Before we could even begin to address the problems surrounding the science, however, we would need to re-consider the laws and foundations on which they were based.

\section{REHABILITATION}

\section{A. The myth of rehabilitation}

In order to examine rehabilitation, we must begin by looking at the focus of civil commitment and incarceration..$^{40}$ Prison's main purpose is

37. Shoba Sreenivasan et al., Alice In Actuarial-Land: Through the Looking Glass of Changing Static-99 Norms, 38 J. AM. ACAD. PSYChIATRY. \& L. 400, 401 (2010) (When designers of the original Static-99 sexual offense recidivism actuarial tool analyzed newer Static-99 studies, they found that the recidivism rates reported in the original Static-99 norms were not holding firm because they were based on recidivism rates from the $1970 \mathrm{~s}$ and $1980 \mathrm{~s}$, which were higher than current rates. The Static-99 designers determined that re-norming was warranted in order to create a more accurate actuarial tool).

38. Hendricks, 521 U.S. at 357 (Breyer, J., dissenting) ("We have consistently upheld such involuntary commitment statutes provided the confinement takes place pursuant to proper procedures and evidentiary standards.") (citing Foucha v. Louisiana, 504 U.S. 71, 80 (1992) and Addington v. Texas, 441 U.S. $418,426-27$ (1979)).

39. Id. at 359 ("[S]tates have, over the years, developed numerous specialized terms to define mental health concepts. Often, those definitions do not fit precisely with the definitions employed by the medical community. The legal definitions of 'insanity' and 'competency, for example, vary substantially from their psychiatric counterparts."); see, e.g., id. at 360 ("Hendricks' diagnosis as a pedophile, which qualifies as a 'mental abnormality' under the Act, thus plainly suffices for due process purposes."); see also Heather Ellis Cucolo, Hebephilia and Pedohebephilia: Implications for Law and Policy, 12 SEx OfFENDER L. REP. 55, 56, 63 (2011) (explaining the potential issues that may result from allowing hebephilia, a disorder not currently recognized in the Diagnostic and Statistical Manual of the American Psychiatric Association, to justify indefinite confinement of sexual offenders by reason of mental disorder).

40. See KURT Bumby, CTR. FOR SEX OfFEnder MGMT., UNDERSTANDING TREATMENT For ADULTS AND JUVENILES WHO HAVE COMMITTED SEX OFFENSES 9 (2006), available at http://www.csom.org/pubs/treatment_brief.pdf ("For professionals in the sex offender management field, it is virtually impossible to avoid the inevitable question about whether sex offenders can be treated or rehabilitated. A definitive response-either in the negative or affirmative-would imply that a simple answer exists, when in reality, the answer is not a clear-cut one. Yet as is often the case in the social and behavioral sciences, there tends to be evidence on either side of the issue of interest. The same holds true with research on sex offender treatment, whereby both skeptics and advocates can produce some level of empirical evidence to support their respective positions."); see also Donna Schram \& Cheryl Milloy, Sexually Violent Predators and Civil Commitment: A Siudy of the Characteristics and Recidivism of Sex Offenders Considered for Civil Commitment But for Whom Proceedings Were Declined, Doc. No. 98-02-1101, WAShINGTON STATE INSTITUTE FOR PUBLIC POLICY at i (1998), available at http://www.wsipp.wa.gov/pub.asp?docid-98-02-1101 (explaining that when tracking the 
punishment, and since prisons are generally designed to neither foster nor seriously invest in inmate rehabilitation, ${ }^{41}$ any specific treatment for sex offenders is an "added bonus" outside of the reason for incarceration. ${ }^{42}$ Once an individual enters sex-offender civil commitment, ${ }^{43}$ the focus is ostensibly no longer on punishment but containment with an emphasis on treatment. ${ }^{44}$ In order to comport with constitutional mandates, the treatment must be offered such that the conditions of confinement do not become punitive. ${ }^{45}$ In upholding a state sex offender civil commitment statute in Hendricks, the Supreme Court offered little insight into the standards for treatment. ${ }^{46}$ Subsequent case law has discussed treatment for sex offenders, but focused mainly on whether certain aspects of confinement invalidated the civil nature of the statute. ${ }^{47}$ Treatment has never been deemed a

official records of sixty-one sex offenders who had been released during the first 6 years of the Washington Community Protection Act of 1990, they found that $41 \%$ ofthegroupwerenotrearrestedatameanfollow-upofalmostfouryears, and, of the $59 \%$ who were rearrested, only $28 \%$ had committed further sex offenses; the nonoffenderscouldhavebeensubjectedtolifesentenceswithoutparole)

41. Michelle Phelps, Rehabilitation in the Punitive Era: The Gap Between Rhetoric and Reality in U.S. Prison Programs, 45 L. \& SoC'Y REV. 33, 34-35 (2011) (discussing the seemingly punitive nature of the current penal system in the United States that has replaced the more rehabilitation-focused correctional facilities and programs of the past).

42. See BUMBY, supra note 40, at I (asserting that often sex offender specific treatment is denied or not offered while an individual is serving a criminal sentence, leading to a "punish first, treat later" strategy).

43. Compare Wyatt v. Stickney, 344 F. Supp. 373, 377 (M.D. Ala. 1972), aff'd in part, rev'd in part, Wyatt v. Aderholt, 303 F.2d 1305 (5th Cir. 1978) ("To deprive any citizen of his or her liberty upon the altruistic theory that the confinement is for humane therapeutic reasons and then fail to provide adequate treatment violates the very fundamentals of due process.") (citations omitted) with Wyatt $\mathbf{v}$. Aderholt, 503 F.2d 1305, 1312 (5th Cir. 1974) ("[W]here the justification for commitment was treatment, it offended the fundamentals of due process if treatment were not in fact provided ... where the justification was the danger to self or to others, then treatment had to be provided as the quid pro quo society had to pay as the price of the extra safety it derived from the denial of individuals' liberty."). For the most recent discussion of "quid pro quo" theory of Wyat in the civil commitment context, see Michael L. Perlin, "Abandoned Love:" The Impact of Wyatt v. Stickney on the Intersection Between International Human Rights and Domestic Mental Disability Law, 35 LAW \& PSYCHOL. REV. 121, 129 30 (2011).

44. See Fabian, supra note 35 , at 82 ("[T] extremely dangerous group of sexually violent predators exist' that need treatment and confinement in a secured setting.").

45. See Hendricks, 521 U.S. at 367-69 (Breyer, J., dissenting) (stating that providing treatment also assures that the conditions and duration of confinement bear a reasonable relation to the purpose for which persons are confined, another requirement of due process); see also Seling v. Young, 531 U.S. 250,265 (2001) ("[D]ue process requires that the conditions and duration of commitment . . . bear some reasonable relation to the purpose for which persons are committed.") (citations omitted).

46. The Hendricks Court used the language "vague and overly broad" in discussing the standards without much further insight; Justice Breyer's dissent suggests that a civil scheme that requires treatment yet systematically denies access to treatment violates both substantive due process and ex post facto clause. Hendricks, 521 U.S. at 378 (Breyer, J., dissenting). The Court in Hendricks conceded that the specific treatment program offered Hendricks "may have seemed somewhat meager." Id. at 367; see also Michael L. Perlin, There's No Success like Failureland Failure's No Success at All: Exposing the Pretextuality of Kansas v. Hendricks, 92 Nw. U. L. REv. 1247, 1264 (1998) (discussing the Court's ambiguous description of what satisfies a state's treatment obligation).

47. See Turay v. Seling, 108 F.Supp.2d 1148, 1151 (W.D. Wash. 2000) (explaining how persons 
constitutional right by the U.S. Supreme Court, ${ }^{48}$ but most states-in an effort to quash challenges alleging punitive detainment-consider it a duty to provide treatment and a "right" of the offender to participate. 49

\section{$B$. What treatment is offered during confinement and how does it prevent future recidivism?}

Our ability to keep sex offenders locked away is dependent on the notion that such detention is civil in nature and holds no punitive intent. To that end, we can constitutionally detain individuals for care and treatment through sex offender civil commitment. ${ }^{50}$ However, there is no consensus as to the effectiveness of treatment or whether the treatment that is made available to this population has had any real effect on risk reduction. ${ }^{51}$ Relatively little is known about which sex offenders will benefit from treatment, what treatment is most effective, and how treatment affects

involuntarily confined through civil proceedings must be afforded adequate treatment); see also In re Det. of Betsworth, 711 N.W.2d 280, 288-89 (lowa 2006) (determining the statutory right to treatment was satisfied as long as an individualized treatment program designed to assist in controlling deviant behaviors was offered).

48. See Youngberg v. Romeo, 457 U.S. 307, 324 (1982) (holding that there is no per se right to rehabilitative training, and minimal training is only required when it is reasonably necessary to avoid an unconstitutional infringement on freedom from undue restraint); Perlin, supra note 43, at 125 ("[The] U.S. Supreme Court eventually failed to constitutionalize some of these holdings in the lead case of Youngberg $v$. Romeo ....").

49. Jeslyn A. Miller, Sex Offender Civil Commitment: The Treatment Paradox, 98 CALIF. L. REV. 2093, 2101 (2010) ("Most state statutes detail treatment either as a 'right' belonging to the committed offender or as a duty of the state.").

50. See, e.g., John Petrila, Because They Do Horrible Things: Fear, Science, and the Erosion of Civil Liberties in Sexually Violent Predator Proceedings, 36 J. PsYCHIATRY \& L. 359, 380 (2008) ("[T] he courts have rarely insisted that treatment be provided, based in part on assumptions that this is a group of individuals for which little exists in the way of treatment."). See also James F. Quinn et al., Societal Reaction to Sex Offenders: A Review of The Origins and Results of the Myths Surrounding Their Crimes and Treatment Amenability, 25 Deviant Behav. 215, 219 (2004) ("The belief that sex offenders are unredeemable predators is so widely accepted in modern society that it provides a rallying point for victims' groups, conservative politicians, and others with the desire to build consensus on the need to make penal sanctions harsher.").

51. See, e.g., In re Young, 857 P.2d 989, 1003 n.7 (Wash. 1993)(“It is by no means clear that the mental abnormalities and personality disorders underlying the sex predator condition are 'untreatable."'), superseded by statute as stated in In re Det. of Thorell, 72 P.3d 708, 720-21 (Wash. 2003); see also Danielle M. Polizzi et al., What Works in Adult Sex Offender Treatment? A Review of Prison- and Non-Prison-Based Treatment Programs, 43 INT'L J. OFFENDER THERAPY \& COMP. CRIMINOLOGY 357, 358 (1999) (addressing the "little consistency in the conclusions drawn from metaanalyses and literature reviews with regard to the effectiveness of sex offender treatment on reducing recidivism."); Michael C. Seto \& Howard E. Barbaree, Psychopathy, Treatment Behavior, and Sex Offender Recidivism, 14 J. INTERPERSONAL VIOLENCE 1235, 1244 (1999) (exploring why uncertainty continues to exist as to whether treatment is detrimental for psychopaths who are considered to be the highest risk of offenders); Jan Looman et al., Does Consideration of Psychopathy and Sexual Deviance Add to the Predictive Validity of the Static-99R?, INT'L J. OFFENDER THERAPY \& COMP. CRIMINOLOLGY (forthcoming 2012), http://ijo.sagepub.com/content/early/2012/05/24/0306624X12444839 (noting that it is unknown whether the disparate levels of treatment subjects received in a psychopath versus sexual deviant recidivism study affected their actual levels of recidivism). 
recidivism..$^{52}$ The question then becomes: does treatment hold any verifiable outcome of effectiveness for this population; and if not, then at what point does it become clear that this detention offers no other purpose but for continued confinement post criminal sentence, thus implicating a punitive statutory design? ${ }^{53}$

In a 2006 article, Drs. Robert Prentky and Barbara Schwartz suggested that, "[p]erhaps the more pressing question, certainly from a public policy standpoint, is 'who' is most likely to be impacted by treatment and how best should they be treated." 54 There is no known cure for inappropriate sexual thoughts or behavior and it is believed that biological (surgical castration and pharmacological interventions) ${ }^{55}$ and non-biological (cognitivebehavioral therapy $)^{56}$ options are the only confirmed methods for reducing risk. ${ }^{57}$ Cognitive-behavioral treatment may include social skills training, sex

52. Marnie E. Rice \& Grant T. Harris, What We Know and Don't Know About Treating Adult Sex Offenders, in Protecting SocietY, supra note 9, at 101, 103 (Bruce K. Winick \& John Q. La Fond eds., 2003)(stating that there are not enough well-controlled studies to accurately determine the benefits of treatment through a meta-analysis).

53. See, e.g., Hendricks, 521 U.S. at 372 (Kennedy, J., concurring) ("If the object or purpose of the Kansas law had been to provide treatment but the treatment provisions were adopted as a sham or mere pretext, there would have been an indication of the forbidden purpose to punish.").

54. Robert Prentky \& Barbara Schwartz, Treatment of Adult Sex Offenders, VAWNET: NAT'L ONLINE RES. CTR. ON VIOLENCE AGAINST WOMEN 6 (Dec. 2006) available at http://www.vawnet.org/Assoc_Files_VAWnet/AR_SexOffendTreatment.pdf.

55. Chemical castration is considered to be potentially effective in its role of reducing obsessive thoughts and/or fantasies in addition to suppressing violent tendencies. It does not have much success in changing the object of one's attraction but can have a marked effect on reducing the desire to act on sexual impulses. See Robert D. Miller, Forced Administration of Sex-Drive Reducing Medications to Sex Offenders: Treatment or Punishment?, 4 PSYCHOL. PUB. POL'Y \& L. 175, 181-83 (1998) (discussing that the model for effective pharmacological treatment for sex offenders is based on the notion that medication must suppress the psychological component of sexual deviation, which causes the deviant sexual fantasies, and thereby inhibit the physical sexual arousal).

56. For studies and articles which use or support the use of cognitive behavioral therapy for sex offenders, see James R. Worling \& Tracey Curwen, Adolescent Sexual Offender Recidivism: Success of Specialized Treatment and Implications for Risk Prediction, 24 CHILD ABUSE \& NEGLECT 965, 968 (2000) ("[W]e utilize the repertoire of cognitive-behavioral and relapse prevention strategies that are currently popular in adolescent and adult sexual offender treatment . . .."); W.L. Marshall \& Dana Anderson, Do Relapse Prevention Components Enhance Treatment Effectiveness?, in REMAKING RElaPSE PREVENTION With SEX OfFenders: A SOURCebook39, 46 (D. Richard Laws et al., 2000) (discussing the effect of relapse prevention in the context of cognitive-behavioral therapy); D. Richard Laws \& W.L. Marshall, A Brief History of Behavioral and Cognitive Behavioral Approaches to Sexual Offenders: Part I. Early Developments, 15 SEXuAl ABuSE: J. RES. \& TREATMENT 75, 83, 86 (2003) (discussing generally the history of behavioral therapy and its transitions to current use); ROBERT J. McGrath et al., Current Practices and Emerging Trends in Sexual abuser Management: THE SAFER SOCIETY 2009 NORTH AMERICAN SuRveY 71-74 (The Safer Society Press 2010) (outlining the various forms of behavioral sexual arousal control treatments used in therapy); and STEVE AOS ET al., Wash. State InSt. For Pub. Policy, Evidence-Based adult Corrections Programs: What WORKS AND WHAT DOES NOT 5 (2006), available at http:/www.wsipp.wa.gov/rptfiles/06-01-1201 .pdf ("On average, we found these programs [forms of cognitive-behavioral therapy] significantly reduce recidivism by 8.2 percent.").

57. See Lauren Cox, Treating Pedophiles: Therapy Can Work, But It's a Challenge, MY HEALTH NEwS DAILY (Dec. 15, 2011), http:/www.myhealthnewsdaily.com/2015-treating-pedophiles-therapychallenge.html (quoting Dr. Fred Berlin and David Prescott, who state that "[t]wo decades of published 
education, cognitive restructuring, aversive conditioning and victim empathy therapy. ${ }^{58}$

The treatment model thus far has been a treatment-as-management approach, 59 "includ[ing] cognitive behavioral treatment to recondition thoughts, feelings, and behaviors, relapse prevention to support and monitor self-management skills in avoiding high risk situations and places." ${ }^{60}$ Commentators have stated that sex offender "civil commitment, in particular, has been described by civil libertarians as preventive detention masquerading as coerced treatment that threatens rehabilitation, justice, and constitutional values, and legitimizes warehousing."61 Additionally, treatment providers in these institutions may lack competency and qualification, which supports the notion that treatment is only in place to make the case for continued confinement after prison. ${ }^{62}$

A 2011 study by the Program Evaluation Division of the State of Minnesota's Office of Legislative Auditor (OLA), ${ }^{63}$ looking at Minnesota's sex-offender civil commitment scheme, found:

- The number of civilly-committed sex offenders in the Minnesota Sex Offender Program (MSOP) nearly quadrupled during the last decade and is expected to nearly double over the next ten years. ${ }^{64}$

- The number of court commitments as a percentage of referrals from the Department of Corrections varies significantly across the state..$^{65}$

- OLA's statistical analysis suggests that some sex offenders

work with sex offenders haven't produced a cure . . . Instead, therapists aim to help pedophiles resist their urges .... We don't know how to change the fact that a person is sexually attracted to children."); Karen J. Terry, Sexual Offenses and Offenders: Theory, Practice, AND POliCy 152-63 (2006) (summarizing types of medical treatments, cognitive-behavioral treatments, and prison treatment programs); see also Reinhard Wille \& Klaus M. Beier, Castration in Germany, 2 ANNALS SEX RES. 103,125 (1989) (finding in a study in Nazi Germany that the recidivism rate of surgically-castrated sex offenders was $3 \%$ compared to a $46 \%$ recidivism rate for non-castrated sex offenders); Ariel Rösler \& Eliezer Witztum, Pharmacotherapy of Paraphilias in the Next Millennium, 18 BEHAV. SCI. \& L. 43, 44 (2000) ("Most of the patients are currently treated with some form of psychotherapy or pharmacotherapy, or a combination of both.").

58. Richard B. Krueger \& Meg S. Kaplan, Behavioral and Psychopharmacological Treatment of the Paraphilic and Hypersexual Disorders, 8 J. PSYCHIATRIC PRAC. 21, 24-25 (2002).

59. Astrid Birgden \& Heather Ellis Cucolo, The Treatment of Sex Offenders: Evidence, Ethics and Human Rights,23 SEXUAL ABUSE: J. RES. \& TREATMENT295, 299-300 (2011).

60. Id. at 299 .

61. Id. at 303.

62. See, e.g., WEST VIRGINIA REPORT, supra note 14("Sex offender assessment and treatment requires an approach unfamiliar to most mental health professionals. At this time, West Virginia does not require any formal process of certification or licensure of those providing treatment or diagnostic services to sex offenders, creating inconsistencies in the methods and underlying philosophical framework of treatment programs and services."); see also MCGRATH ET. AL., supra note 56, at 33(stating fewer than one-fifth of United States providers hold doctoral degrees).

63. MINN. OfFICE OF LEGIS. AUDITOR, CIVIL COMMITMENT OF SEX OFFENDERS (2011), available at http://www.auditor.leg.state.mn.us/ped/pedrep/ccso.pdf.

64. Id. at ix, 3-5.

65. Id. at ix, 34 . 
being committed may have a lower risk of recidivism than others who are being released from prison. ${ }^{66}$

- Minnesota lacks reasonable alternatives to commitment at a high security facility. Lower-cost alternatives may be appropriate for some sex offenders being considered for commitment or already residing at MSOP facilities. ${ }^{67}$

- No sex offender has been discharged from MSOP since it was created in $1994 .{ }^{68}$ Without releases, Minnesota is susceptible to lawsuits challenging the adequacy of the treatment program. ${ }^{69}$

- MSOP's treatment program has experienced frequent leadership changes and significant staff vacancies, and it has struggled to maintain the type of therapeutic environment necessary for treating high-risk sex offenders. ${ }^{70}$

- Current MSOP management has worked to address security problems and clinical deficiencies, but it still needs to increase the number of treatment hours provided, improve the therapeutic environment, and establish clearer guidelines for judging treatment progress. ${ }^{71}$

Recently, the conditions at MSOP have been the subject of a class action lawsuit contesting the constitutionality of locking away offenders for gross extensions of time. ${ }^{2}$ Potentially, the above findings may suggest a punitive intent of confinement and call into question the realities of treatability of this population given the fact that the release rate has been almost nonexistent within the seventeen years that the program has been up and

66. Id. at ix, 39 .

67. Id. at ix, 42-44.

68. Id. at ix, 19. However, this is not entirely accurate. See Judicial Panel Gives Final OK On Discharge of Sex Offender From Minnesota Program, TWIN CITIES (Feb. 10, 2012), http:/www.twincities.com/localnews/ci_19940882?IADID=Search-www.twincities.com-

www.twincities.com (reporting that the state released an offender in 2000, but he violated the terms of his release and was returned to the program in 2003); Warren Wolfe, A Turning Point for State's Sex Offender Program, STAR TRIBUNE (Minn.), Feb. 19, 2012, http://www.startribune.com/local/stpaul/139595093.html (reporting that a second offender was approved for release in February 2012); see also lan Evans, Britain Denies Extradition of Minnesota Sex Suspect, STAR TRIBUNE (Minn.), June 28, 2012, http://www.startribune.com/local/160704485.html (reporting that the Minnesota program made intemational news recently when a London (UK) High Court refused to return an alleged sex offender to Minnesota to face criminal charges after officials in Hennepin and Dakota counties refused to guarantee he would not be committed to the state's controversial sex offender program, because such institutionalization "would be a 'flagrant denial' of Sullivan's human rights under Article 5 of the European Convention on Hurnan Rights.").

The authors wish to thank Anita Schlank, Jack B. Schaffer and John Austin for their assistance in bringing this information to their attention.

69. MINN. OFFICE OF LEGIS. AUDITOR, supra note 63, at ix, 52.

70. Id. at ix, 58-61, 65-72.

71. Id. at ix.

72. See, e.g., Mary Lynn Smith \& Dave Hage, Minnesota Sex-Offender Lawsuit Takes Step Forward, STAR TRIBUNE (Minn.), July $25, \quad 2012$, http:/www.startribune.com/local/163607246.html?refer=y (reporting on a lawsuit challenging the constitutionality of Minnesota's sex offender treatment program). 
running. ${ }^{73}$

\section{Why is so little attention paid to rehabilitation?}

This all raises the rarely-asked question: why is so little attention paid to rehabilitation? A review of the treatment offered and the facilities designed to contain individuals who have committed sexual offenses seems to confirm the answer that society has no intention or desire to return these individuals to the community. ${ }^{74}$ For many people, the phrase "sex offender" automatically implies "monstrous imminent evil.""75 Public pressure on politicians calls for sex offenders to be effectively managed through deterrence-based methods, ${ }^{76}$ though the academic community propounds therapeutic methods. ${ }^{77}$ Treatment for sex offenders has been defined as "the delivery of prescribed interventions as a means of managing crimeproducing factors and promoting positive and meaningful goal attainment for participants, all in the interest of enhancing public safety." 78 When designing containment laws, legislative goals have been directed towards making the public feel safer, rather than helping the offender live successfully and thrive as a member of the community upon his

73. See Wolfe, supra note 68.

74. See, e.g., MINN. STAT. $\$ 253$ B.185, subdiv. 18 (2011) ("A patient who is committed as a sexual psychopathic personality or sexually dangerous person shall not be discharged unless it appears to the satisfaction of the judicial appeal panel, after a hearing and recommendation by a majority of the special review board, that the patient is capable of making an acceptable adjustment to open society, is no longer dangerous to the public, and is no longer in need of inpatient treatment and supervision. In determining whether a discharge shall be recommended, the special review board and judicial appeal panel shall consider whether specific conditions exist to provide a reasonable degree of protection to the public and to assist the patient in adjusting to the community. If the desired conditions do not exist, the discharge shall not be granted."). See generally Sarah E. Spierling, Lock Them Up and Throw Away the Key: How Washington's Violent Sexual Predator Law Will Shape the Future Balance Between Punishment and Prevention, 9 J.L. \&POL'Y 879, 899-903 (2001) (discussing how many sexual predator statutes undermine effective therapy by "delaying treatment until after a criminal sentence has been served" and by forcing offenders to undergo treatment, and articulating the views of some prosecutors that the primary purpose of civil commitment after a criminal sentence is to "ensure the commitment of these persons in order to protect the community" rather than to rehabilitate the offender).

75. See, e.g., Christina Hebel, 'An Unsuitable Instrument' for Sex Offenders: EU Politicians Angered By Polish Chemical Castration Plan, SPIEGEL ONLINE INT'L, Sep. 25, 2008, http://www.spiegel.de/international/europe/0,1518,580284,00.html (noting that Polish Prime Minister, Donald Tusk, has called for the introduction of forced chemical castration for sex offenders, saying that in the case of sex offenders, "one can't even argue on behalf of human rights" since he "[doesn't] believe such individuals, such creatures, can be called human"); see Jonathan Simon, Sanctioning Government: Explaining America's Severity Revolution, 56 U. MIAMI L. REv. 217, 229 (2001) (characterizing the public view of sex offenders as "those who are perceived as in the grip of evil or monstrous desires").

76. E.g., Kenneth Crimaldi, “Megan's Law”: Election-Year Politics and Constitutional Rights, 27 RUTGERS L.J. 169, 169 n.2, 172 (1995) (discussing how the media and public attention given to Megan Kanka's assault and murder pressured the New Jersey legislature to enact a mandatory community notification policy, "Megan's Law," which was based on a perception that sex offenders were more difficult to rehabilitate, and thus recidivate at higher rates).

77. See Laurie O. Robinson, Sex Offender Management: The Public Policy Challenges, 989 ANNALS N.Y. ACAD. SCl. I, 2 (2003) (asserting that punitive measures alone cannot solve the sex offender policy problem and that multidisciplinary approaches are necessary).

78. BumBY, supra note40, at 2. 
release. ${ }^{79} \mathrm{Any}$ focus on human rights and rehabilitation for sex offenders has been put forth on a limited basis by the academic community, and has been severely neglected in the legislatures and courts. ${ }^{80}$

\section{ANTI-THERAPEUTIC AND INHUMANE SOLUTIONS UPON RELEASE}

\section{A. Are individuals who have committed sex offenses unworthy of constitutional and legal protections?}

States (and the federal government) have enacted laws to attempt to reduce recidivism and to ensure that certain offenders are monitored in the community, once civil or criminal confinement ends. ${ }^{81}$

In 1994, New Jersey enacted Megan's Law in response to community outrage in the aftermath of the brutal rape and murder of seven-year-old Megan Kanka by a convicted sex offender. ${ }^{82}$ This horrific offense was the catalyst $^{83}$ behind a law that would track all convicted sex offenders and publicly display where they resided in the community. ${ }^{84}$ Parallel legislation to Megan's Law was subsequently enacted on the federal level to further

79. See Charles L. Scott \& Trent Holmberg, Prisoners' Rights Versus Public Safety, 31 J. AM. ACAD. PSYCHIATRY \&L. 502, 503 (2003) (summarizing a number of punitive legislative strategies recently enacted to penalize and isolate sex offenders from the public).

80. Beyond the scope of this paper is an analysis of the application of the United Nations' Convention on the Rights of Persons with Disabilities to this population. For a general discussion of that document, see, for example, Michael L. Perlin, "A Change Is Gonna Come": The Implications of the United Nations Convention on the Rights of Persons with Disabilities for the Domestic Practice of Constitutional Mental Disability Law, 29 N. ILL. U. L. REV. 483, 489-97 (2009); for a discussion of its implications for forensic populations, see MICHAEL L. PERLIN, INTERNATIONAL Human RIGHTS AND MENTAl Disability LAW: WhEn the SilenCEd ARE HEARD, 100-01 (2012); for a discussion of the implications of international human rights instruments for forensic patients and correctional inmates in general, see Astrid Birgden \& Michael L. Perlin, "Where the Home in the Valley Meets the Damp Dirty Prison": A Human Rights Perspective on Therapeutic Jurisprudence and the Role of Forensic Psychologists in Correctional Settings, 14 AGgRESSION \& VIOLENT BEHAV. 256, 257-58 (2009); Astrid Birgden \& Michael L. Perlin, 'Tolling for the Luckless, the Abandoned and Forsaked': Therapeutic Jurisprudence and International Human Rights Law as Applied to Prisoners and Detainees by Forensic Psychologists, 13 LeGal \& CRIMINologICAL PSYCHOL. 231, 234-38 (2008); Michael L. Perlin \& Henry A. Dlugacz, "It's Doom Alone That Counts": Can International Human Rights Law Be an Effective Source of Rights in Correctional Conditions Litigation?, 27 BEHAV. SCI. \& L. 675, 691-94 (2009).

81. See, e.g., N.J. STAT. ANN. § 2C:7-1 (West 2005) ("The legislature finds and declares: a. The danger of recidivism posed by sex offenders and offenders who commit other predatory acts against children ... require[s] a system of registration that will permit law enforcement officials to identify and alert the public when necessary for the public safety.").

82. Karen Newburn, The Prospect of an International Sex Offender Registry: Why an International System Modeled After United States Sex Offender Laws Is Not an Effective Solution to Stop Child Sexual Abuse, 28 WIS. INT'L L.J. 547, 548-49 (2010) (describing the details of the crime committed against Megan Kanka and the legislative response).

83. $l d$.

84. Under Megan's Law, offenders must register their address with local authorities; they are placed into one of three tiers based on their perceived level of risk. Megan's Law, N.J. STAT. ANN. $\$ 2 C: 7$ (West 2005 \& Supp. 2012); Artway v. Att'y Gen. of N.J., 81 F.3d 1235, 1243 (3d Cir. 1996) (upholding registration aspects of New Jersey's Megan's Law). 
compel conformity among the states. ${ }^{85}$ Within this legislation was the authorization to create a national registry of offenders who are convicted of coercive, penetrative sex with anyone, and/or offenders who have had sex with children under the age of twelve. ${ }^{86}$ By 2005 , this national registry was available on the Internet and was linked to twenty-two state online registries. ${ }^{87}$ In 2006, Congress enacted the Adam Walsh Child Protection and Safety Act. ${ }^{88}$ This legislation contains the Sex Offender Registration and Notification Act (SORNA), ${ }^{89}$ which has increased the pool of individuals required to register as well as the length of time that they are required to register..$^{90}$ In order to expand the group of individuals subject to registration, Congress broadly defined sex offense as a "criminal offense that has an element involving a sexual act or sexual contact with another," in addition to other enumerated categories of offenses. ${ }^{11}$ SORNA greatly expanded qualifying crimes and offenses and departed from tradition significantly in its treatment of juvenile offenders..$^{92}$ By 2006 , all fifty states and the District of Columbia had enacted some form of community

85. Megan's Law, Pub. L. No. 104-145, 110 Stat. 1345 (1996) (codified at 42 U.S.C. $§ 14071(d)$ ) (repealed 2006).

86. See Dep't of Justice, OfF. Of THE ATT'y Gen., A.G. ORder No. 2196-98, MEgan's Law; FINAL GUIDELINES FOR THE JACOB WETTERLING CRIMES AGAINST CHILDREN AND SEXUALly VIOLENT OFFENDER REGISTRATION ACT, AS AMENDED, (Dec. 17, 1998), available at

http:/pub.bna.com/cl/19990120/2196.htm (defining aggravated offenses as "state offenses comparable to aggravated sexual abuse as defined in federal law (18 U.S.C. 2241), which principally encompasses:(1) engaging in sexual acts involving penetration with victims of any age through the use of force or the threat of serious violence; and (2) engaging in sexual acts involving penetration with victims below the age of 12").

87. Press Release, Dep't of Justice, Off. of Justice Programs, Department of Justice Activates National Sex Offender Public Registry Website: Twenty-Two States Accessible from National Website, (July 20, 2005), http://www.amberalert.gov/newsroom/pressreleases/ojp_05_0720.htm.

88. Adam Walsh Child Protection and Safety Act of 2006, Pub. L. 109-248, 120 Stat. 587 (2006) (codified in scattered sections of 8 U.S.C., 18 U.S.C., \& 42 U.S.C.). See generally Lori McPherson, Practitioner's Guide to the Adam Walsh Act, UPDATE: NAT'L CTR. FOR PROSECUTION OF CHILD ABUSE, no. $9 \& 10,2007$, at 1 , available at http://www.ojp.usdoj.gov/smart/pdfs/practitioner_guide_awa.pdf (providing guidance for prosecutors on new provisions in the Adam Walsh Act).

89. Sex Offender Registration and Notification Act, 42 U.S.C. $\$ \$ 16911-29$ (2006).

90. See McPherson, supra note 88 , at 2 (explaining requirements of SORNA, which expand the length of time during which offenders must be registered, increase the amount of detailed information required, and apply to more tiers of offenders).

91. 42 U.S.C. \$ 16911(5)(A). According to HUMAN RightS WATCH, No Easy Answers: Sex Offender Lows in the U.S., 19, HUMAN RIGHTS WATCH 1, 39-40 (2007), at least five states require registration for adult prostitution-related offenses; thirteen states require registration for public urination; twenty-nine states require registration for consensual sex between teenagers; and thirty-two states require registration for exposing genitals in public. See also Rainer v. State, 690 S.E.2d 827, 828-29 (Ga. 2010) (upholding provision of the state's sex offender registry law that requires the registration of certain persons not convicted of sex crimes).

92. Michael F. Caldwell et al., An Examination of the Sex Offender Registration and Notification Act as Applied to Juveniles Evaluating the Ability to Predict Sexual Recidivism, 14 PSYCHOL. PUB. POL'Y \& L. 89, 105-06 (2008) (noting that a provision of SORNA that redefines juvenile court adjudication for a sexual offense as synonymous with conviction is a departure from the common view of juvenile delinquency as different from adult criminal behavior). See generally Doe v. Weld, $954 \mathrm{~F}$. Supp. 425, 426-27 (D. Mass. 1997) (holding Massachusetts' juvenile statute constitutional). 
notification and registration requirements. ${ }^{93}$ As of 2008 , thirty states had enacted residency restrictions for offenders in the community. ${ }^{94}$

In order to effectively comply with SORNA, state public websites must include:

The name of the sex offender, including any aliases.

The address of each residence at which the sex offender resides or will reside and, if the sex offender does not have any (present or expected) residence address, other information about where the sex offender has his or her home or habitually lives. If current information of this type is not available because the sex offender is in violation of the requirement to register or is unable to be located, the website must so note.

The name and address of any place where the sex offender is an employee or will be an employee and, if the sex offender is employed but does not have a definite employment address, other information about where the sex offender works.

The name and address of any place where the sex offender is a student or will be a student.

The license plate number and a description of any vehicle owned or operated by the sex offender.

A physical description of the sex offender.

The sex offense for which the sex offender is registered and any other criminal offense for which the sex offender has been convicted.

A current photograph of the sex offender. ${ }^{95}$

Failure to comply is a violation of federal law and the offender is either fined or imprisoned. ${ }^{96}$ Ignoring Supreme Court precedent, ${ }^{97}$ and acting

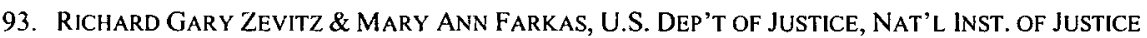
SEX OFFENDER COMMUNITY NOTIFICATION: ASSESSING THE IMPACT IN WISCONSIN 1-2 (Dec. 2002) available atwww.ncjrs.gov/pdffiles 1/nij/179992.pdf.

94. Michelle L. Meloy, et al., Making Sense Out of Nonsense: The Deconstruction of State-Level Sex Offender Residence Restrictions, 33 AM. J. CRIM. JUST. 209, 214 (2008).

95. 73 Fed. Reg. 38030, 38059(July 2, 2008) (explaining registration requirements in 42 U.S.C. $\S$ 16914 \& 16918); U.S. ATT'Y GEN., THE NATIONAL GUIDELINES FOR SEX OFFENDER REGISTRATION AND NOTIFICATION-FINAL GUIDELINES $36 \quad(2008)$, available at http://www.ojp.usdoj.gov/smart/pdfs/final_sornaguidelines.pdf.

96. 18 U.S.C. $\$ 2250(a)(3)(2006)$ (stating that a sex offender found in violation shall be fined or imprisoned not more than ten years, or both); see also Richard Tewksbury, Collateral Consequences of Sex Offender Registration, 21 J. CONTEMP. CRIM. JUST. 67, 69 (2005) (highlighting some of the legally mandated consequences of failure to register as a sex offender under SORNA).

97. Since 1995, the Supreme Court has struck down the regulation of non-economic criminal activity under the Commerce Clause as an intrusion on the police power authority of the states. See, e.g., United States v. Morrison, 529 U.S. 598, 618 (2000) ("Indeed, we can think of no better example of the police power, which the Founders denied the National Government and reposed in the States, than the suppression of violent crime and vindication of its victims."); United States v. Lopez, 514 U.S. 549, $562-63$ (1995) ("We agree with the Government that Congress normally is not required to make formal findings as to the substantial burdens that an activity has on interstate commerce . . . But to the extent that congressional findings would enable us to evaluate the legislative judgment that the activity in question substantially affected interstate commerce, even though no such substantial effect was visible to the naked eye, they are lacking here."). 
without any express legislative findings regarding an impact on interstate commerce, ${ }^{98}$ Congress invoked the Commerce Clause to authorize the federalization of registration violations. ${ }^{99}$

In 2007 administrative authorization retroactively applied the Adam Walsh Act to successfully develop a "comprehensive" system, which would be effective in protecting the public by widening the scope to include all offenders-regardless of when they were convicted.100 Therefore, a defendant is de facto a criminal the moment the law goes into effect and can be prosecuted for" failure to register" without an allegation of any subsequent offense. ${ }^{101}$ This is directly in violation of prior Supreme Court mandates that an element of a crime should not be viewed as continuing "unless the explicit language of the substantive criminal statute compels such a conclusion, or the nature of the crime involved is such that Congress must assuredly have intended that it be treated as a continuing one." 102 Although Congress has echoed the unverified conclusion that individuals who commit sexual offenses are likely to re-offend, it has done so without specific legislative support. ${ }^{103}$ By continuing to criminalize an element of the crime through retroactive application of the law and by further criminalizing failure to register, Congress has overstepped its constitutional authority. ${ }^{104}$

Community notification and residency restriction laws have been criticized as immoral, cruel and inhumane, and detrimental to the goal of reducing sexual offending. ${ }^{105}$ The efficacy of these laws has been sharply

98. Congress' authority to act has generally been preconditioned on legislative findings. The Supreme Court echoed this notion in the prominent area of affirmative action where specific legislative findings were required. See, e.g., Adarand Constructors, Inc. v. Pena, 515 U.S. 200, 236 (1995)(requiring Congress to justify affirmative action legislation with specific findings because "classifications based on race are potentially so harmful to the entire bodypolitic, itisespeciallyimportantthatthereasonsforanysuchclassificationbe clearly identified") (quoting Fullilove v. Klutznick, 448 U.S. 448, 534 (1980) (Stevens, J., dissenting)); Richmond v. J.A. Croson Co., 488 U.S. 469, 504 (1989) (stating legislatures "must identify that discrimination, public or private, with some specificity before they may use race-conscious relief').

99. Previously state crimes, registration violations are now punished by federal sanctions. See United States v. Madera, 474 F.Supp.2d 1257, 1265 (M.D. Fla. 2007)(unsuccessfully challenging the Adam Walsh Act registration provision on several bases including the Commerce Clause), rev'd on other grounds, 528 F.3d 852 (11 th Cir. 2008).

100. Applicability of the Sex Offender Registration and Notification Act, 28 C.F.R. $\$ 811.1$ (2012).

101. Id. at $\$ 811.3(\mathrm{~b})$.

102. Corey Rayburn Yung, The Disappearing Ex Post Facto Clause: From Substantive Bulwark to Procedural Nuisance, 61 SYR. L. REV.447, 452 (2011) (quoting United States v. Toussie, 397 U.S. 112, $115(1970))$.

103. See United States v. Buxton, No. CR-07-082-R, 2007 U.S. Dist. LEXIS 76142, at *10 (W.D. Okla. Aug. 30, 2007) ("Congress expressly stated that the purpose of SORNA was 'to protect the public from sex offenders and offenders against children.")

104. See, e.g., Lopez, 514 U.S. at 564 ("The Government admits, under its 'costs of crime' reasoning, that Congress could regulate not only all violent crime, but all activities that might lead to violent crime, regardless of how tenuously they relate to interstate commerce . . . Under the theories that the Govemment presents . . it is difficult to perceive any limitation on federal power, even in areas such as criminal law enforcement or education where States historically have been sovereign.").

105. See Jill S. Levenson \& Leo P. Cotter, The Effect of Megan's Law on Sex Offender Reintegration, 
debated, with many questions surrounding the legality and morality of ostracizing offenders after release, ${ }^{106}$ as well as the weight of the expense generated by these laws ${ }^{107}$ measured against the degree to which they protect the community. ${ }^{108}$ If a criminal has paid his debt to society by concluding his sentence, ${ }^{109}$ how can society limit where he chooses to live upon release? ${ }^{110}$ How have these laws passed constitutional muster and overcome challenges of ex post facto and double jeopardy?"' The present system of registering offenders does not distinguish between those who will be dangerous in the future from those who were formerly dangerous. ${ }^{112}$ It bundles statutory rape cases that deal with sexual interactions between teenagers-interactions that would otherwise be consensual but for the age of one of the partners-with cases of individuals who have committed violent pedophilic offenses. ${ }^{13}$ It seems obvious that such a system is unreliable and unfair. ${ }^{114}$

Additionally, these defendants are forever branded with a "scarlet

$21 \mathrm{~J}$. CONTEMP. CRIM. JUST. 49, 62 (2005) (analyzing data retrieved through an empirical study on the positive and negative consequences of community notification on sex offenders' rehabilitation).

106. See Birgden \& Cucolo, supra note 59, at 304 (arguing that contemporary sex-offender treatment violates rights, is ineffective, and is unethical).

107. Zgoba, supra note 18, at 36 (discussing the costs of implementing Megan's Law, citing particularly a $155 \%$ increase in ongoing expenses between 2006 and 2007).

108. See, e.g., State v. Kedging, 571 N.W.2d 450, 453 (Wis. Ct. App. 1997) (holding that a commitment order was an abuse of discretion where placement options outside of offender's county of residence were not considered); McCreary v. State, 582 So.2d 425, 428 (Miss. 1991) ("[B]anishmcnt from a large geographical area ... struggles to serve any rehabilitative purpose . ...”); MINN. DEP'T OF Corr., Level Three Sex Offenders: Residential Placement Issues, 2003 Report to the LEGISLATURE 9 (2003) (observing sex offender proximity to schools or parks is not associated with recidivism).

109. Margaret Colgate Love, Paying Their Debt to Society: Forgiveness, Redemption, and the Uniform Collateral Consequences of Conviction Act, 54 How. L.J. 753, 767 (2011).

110. See United States v. Pitts, No. 07-157-A, 2007 U.S. Dist. LEXIS 82632, at *15 (M.D. La. Nov. 7,2007 ) (holding the statutorily authorized prison sentence of up to ten years for failing to register did not provide reason to find that a prosecution under SORNA was punitive in nature).

111. W.P. v. Poritz, 931 F. Supp. 1199, 1211, 1217 (D.N.J. 1996) (holding Megan's Law constitutional despite ex post facto clause challenge and stating that the notification requirements did not impose "punishment" on sex offenders); United States v. Husted, No. CR-07-105-T, 2007 U.S. Dist. LEXIS 56662, at *10 (W.D. Okla. 2007), rev'd on other grounds, 545 F.3d 1240 (10 ${ }^{\text {th }}$ Cir. 2008) (reversing on statutory interpretation grounds but not on ex post facto clause grounds).

112. See Carl Bialik, How Likely are Sex Offenders to Repeat Their Crimes, WaLL ST. J. NumBerS GUY BLOG (Jan. 24, 2008, 11:35PM), http://blogs.wsj.com/numbersguy/how-likely-are-sex-offendersto-repeat-their-crimes-258/ (noting that the majority of sex-offenders are unlikely to reoffend, while others commit "unusually harmful" acts when they do, but statutory schemes make all offenders comply with registration laws).

113. Steve James, Romeo and Juliet Were Sex Offenders: An Analysis of the Age of Consent and a Call for Reform, 78 U. MO.-KAN. CITY L. REV. 241 (2009); see also Birgden \& Cucolo supra note 59, at 300 (stating that consensual sex between teenagers was included in the 660,000 registered sex offenders as of 2008).

114. In no way do we suggest that criminal behavior should be excused; it absolutely should be criminally prosecuted in accordance with our laws and determinations as to what constitutes a sexual crime. But in the context of monitoring after an individual has been adjudicated for that crime or served his or her criminal sentence, we contend that consideration of the degrees of dangerousness, riskiness and heinousness of the prior crime should be taken into account. 
letter," 15 notwithstanding the fact that they have already been criminally punished for their offenses. Every aspect of their lives-including personal life choices such as place of residence, ${ }^{116}$ employment, ${ }^{117}$ and Internet use ${ }^{118}$ - has the potential to be intruded upon, scrutinized, and judged. Under the law, general criminals (those convicted for non-sexually motivated offenses) are often branded with the after-effects of a criminal conviction when seeking employment or dealing with federal and state agencies, ${ }^{119}$ but nothing else approximates the public display of distrust and alienation directed towards individuals who have committed sexual offenses.

\section{B. How far will we infringe on human rights?}

Although we recognize that the phrase "sex offender" automatically infers "monstrous imminent evil," 120 does that label give us justification to deny human rights mandated under international law? Article 17 of the International Covenant on Civil and Political Rights provides that "[n]o one shall be subjected to arbitrary or unlawful interference with his privacy, family, home or correspondence, nor to unlawful attacks on his honor and reputation." 121 Everyone has the right to the protection of the law against such interference or attacks. Residency restrictions prevent individuals who have committed sexual offenses from living within specific proximities to

115. See, e.g., Lara Geer Farley, The Adam Walsh Act: The Scarlet Letter of the Twenty-First Century, 47 WASHBURNL.J.471, 502 (2008) (arguing against the "scarlet letter" punishment of requiring non-violent offenders who are unlikely to recidivate to register as sex offenders for the rest of their lives).

116. See ZEVITZ \& FARKAS, supra note 93, at 9 (discussing a study of thirty sex offenders in the state of Wisconsin revealed that twenty-three of thirty described being humiliated regularly, ostracized by neighbors and lifetime acquaintances, and harassed or threatened by nearby residents or strangers).

117. See generally Shelley Albright \& Furjen Denq, Employer Attitudes Towards Hiring ExOffenders, 76 PRISON J. 118, 127-35 (1996) (analyzing empirical research conducted on the issues exoffenders face in employment).

118. See Sex Offenders Are Barred from Internet by New Jersey, N.Y. TIMES, Dec. 28, 2007, www.nytimes.com/2007/12/28/nyregion/28offender.html.

119. See generally Love, supra note 109, at 770-74 (discussing the stigmas and difficulties in seeking and maintaining employment post-release from prison, including being rejected for jobs due to private employers "running routine background checks," especially those "businesses hoping for a government contract or grant," as well as being prohibited from volunteer opportunities and discouraged from contributing to politicians' campaigns).

120. See, e.g., Simon, supra note75, at 229 (describing sex offenders as one group of criminals viewed by society as persons "in the grip of evil or monstrous desires"); see also, Joseph E. Kennedy, Monstrous Offenders and the Search for Solidarity Through Modern Punishment, Hastings L.J. 873-76, 881-87 (2001) (discussing the "monstrous" conceptualization of sex offenders, and observing "the social construction of the problem of the sexual abuse of children illustrates perfectly the scapegoating of monstrous offenders as a way of dealing with deeply felt social anxieties").

121. International Covenant on Civil and Political Rights, G.A. Res. 2200A (XXI), art. 17, (Mar. 23, 1976). But see Sosa v. Alvarez-Machain, 542 U.S. 692, 735 (2004) (holding that the ICCPR is not selfexecuting and does not confer a private cause of action: "[A]lthough the Covenant does bind the United States as a matter of international law, the United States ratified the Covenant on the express understanding that it was not self-executing and so did not itself create obligations enforceable in the federal courts."). 
schools, parks and other areas where children congregate. 122 These ordinances are aimed at prohibiting offenders from residing within particular areas and inevitably within particular cities. ${ }^{123}$

Residency restrictions range anywhere from 100 feet to 2500 feet from any designated area in which minors congregate and apply to the individual regardless of the prior criminal or offense history. ${ }^{24}$ Therefore, a criminal whose victims did not include children and who has no history of interest in or attraction to children is still subject to ordinances preventing him from living within a specified distance from places where children may be found. ${ }^{125}$ The case of Doe v. Miller ${ }^{126}$ exemplifies the courts' failure in acknowledging the vast differences within the sex offender population and the resulting offenses, and their refusal to acknowledge and consider scientific data about sex-offending behaviors.

Doe challenged an Iowa law ${ }^{127}$ prohibiting any person convicted of certain sex offenses involving minors from residing within 2000 feet of a school or registered childcare facility. ${ }^{128}$ At trial, no scientific data were introduced regarding how the treatment of certain clinical disorders might affect the risks for sexual recidivism. ${ }^{129}$ The district court found that the statute was unconstitutional and amounted to ex post facto punishment, violated the plaintiffs' rights to avoid self-incrimination, and violated substantive due process, because it infringed on rights to travel and rights to choose how to conduct "family affairs." 130

On appeal, the Eighth Circuit reversed the trial court, concluding that the Constitution did not prevent Iowa from regulating the residency of sex

122. See, e.g., Cobb v. State, 437 So.2d 1218, 1220 (Miss.1983) (upholding a probation condition requiring the defendant to "stay out of Stone County.").

123. See Steven Brown et al,, What People Think About the Management of Sex Offenders in the Community, 47 HOWARD J.259, 272-73 (2008)(explaining a study finding that the public does not necessarily agree with punitive conditions but is insecure in the effectiveness of community containment and concerned about the reality of reintegration); Shelley Ross Saxer, Banishment of Sex Offenders: Liberty, Protectionism, Justice, \& Alternatives, 86 WASH. U. L. REV. 1397, 1405-11 (2009) (explaining how sex offender residency restrictions "banish" sex offenders from living in certain areas or communities).

124. Corey Rayburn Yung, Banishment by a Thousand Laws: Residency Restrictions on Sex Offenders, 85 WASH. U. L. REV. 101 at 122-26 (2007) (noting various state residency restrictions).

125. See id. at 123 (noting that most states apply residency restrictions to those whose crimes did not involve children).

126. 298 F. Supp. 2d 844, 870 (S.D. Iowa 2004), rev'd, 405 F.3d 700 (8th Cir. 2005).

127. IOWA CODE ANN. $\S 692$ A.2A (West 2004) ("l. For purposes of this section, 'person' means a person who has committed a criminal offense against a minor, or an aggravated offense, sexually violent offense, or other relevant offense that involved a minor. 2. A person shall not reside within two thousand feet of the real property comprising a public or nonpublic elementary or secondary school or a childcare facility. 3. A person who resides within two thousand feet of the real property comprising a public or nonpublic elementary or secondary school, or a childcare facility, commits an aggravated misdemeanor.').

128. Id.

129. See Doe, 298 F. Supp. 2d at 876 (noting that while this case primarily focused on proximity restrictions, no data was shown to illustrate the relationship between proximity restrictions and recidivism).

130. Id. at $872-80$. 
offenders in order to protect the health and safety of its citizens. ${ }^{131}$ Significant in the majority opinion is the failure to consider any information regarding how the treatment of certain clinical disorders might affect the risks for sexual recidivism. ${ }^{132}$ Furthermore, the court failed to consider any of the amicus briefs that were designed to educate the court about the relevant science and data. ${ }^{133}$ Only the dissent speaks to the potential problems in applying the Iowa law to all convicted offenders, regardless of their history and risk of re-offending. ${ }^{134}$ Further, it faults the Iowa law for viewing all sex offenders as being at equal risk of recidivism. ${ }^{135}$

Due to the restrictions upheld by the Doe court, individuals may be uprooted and forced to move from established residences, may be unable to return home after prison, and may be prevented from residing with their own children, thus further disabling the family unit and removing the needed support of family members. ${ }^{136}$ One such example involves the case

\section{Doe, 405 F.3d at 705 .}

132. See id. at 716 (noting that expert testimony suggested reducing opportunity and temptation to minimize the possibility of re-offense).

133. See id. at 709 ("We likewise conclude that the lowa residency restriction does not contravene principles of procedural due process under the Constitution. The restriction applies to all offenders who have been convicted of certain crimes against minors, regardless of what estimates of future dangerousness might be proved in individualized hearings. Once such a legislative classification has been drawn, additional procedures are unnecessary, because the statute does not provide a potential exemption for individuals who seek to prove that they are not individually dangerous or likely to offend against neighboring schoolchildren. Unless the Does can establish that the substantive rule established by the legislative classification conflicts with some provision of the Constitution, there is no requirement that the State provide a process to establish an exemption from the legislative classification") (citation omitted). See also id. at 714 ("The Does contend, however, that the statute is irrational because there is no scientific study that supports the legislature's conclusion that excluding sex offenders from residing within 2000 feet of a school or child care facility is likely to enhance the safety of children. We reject this contention because we think it understates the authority of a state legislature to make judgments about the best means to protect the health and welfare of its citizens in an area where precise statistical data is unavailable and human behavior is necessarily unpredictable. Although the Does introduced one report from the Minnesota Department of Corrections finding 'no evidence in Minnesota that residential proximity of sex offenders to schools or parks affects reoffense,' this solitary case study - which involved only thirteen reoffenders released from prison between 1997 and 1999-does not make irrational the decision of the Iowa General Assembly and the Governor of Iowa to reach a different predictive judgment for Iowa. As the district court observed, twelve other States have enacted some form of residency restriction applicable to sex offenders.") (footnote omitted).

134. Id. at 726 (Melloy, J., dissenting). The dissent makes note of the varying degrees of sexual offenses:

However, the restriction also applies to John Doe II, who pleaded guilty to third degree sexual abuse for having consensual sex with a fifteen-year-old girl when he was twenty years old. The restriction applies to John Doe VII, who was convicted of statutory rape under Kansas law. His actions, which gave rise to this conviction, would not have been criminal in lowa. The restriction applies also to John Doe XIV, who pleaded guilty to a serious misdemeanor charge in 1995 after he exposed himself at a party at which a thirteenyear-old girl was present. John Doe XIV was nineteen at the time of his offense.

Id.

135. See id. (pointing out that the lowa residency restriction "is applied to all offenders identically. . mak[ing] the residency restriction excessive").

136. See Jill Levenson \& Richard Tewksbury, Collateral Damage: Family Members of Registered Sex Offenders, 34 AM. J. CRM. JUST. 54, 55-56 (2009) (noting housing disnuption is a common result of 
of Wendy Whitaker, who engaged in a single act of consensual oral sex with a fifteen year old when she was seventeen years old. ${ }^{137}$ She was arrested and charged with the crime of sodomy. ${ }^{138}$ Over ten years later, she was forced from her home because of its proximity to a childcare center. ${ }^{139}$ After the Georgia Supreme Court in Mann v. Georgia Department of Corrections ${ }^{140}$ held that the Georgia statute which prohibited registered sex offenders from residing within 1000 feet of any child care facility, school or church where minors congregate, was an impermissible taking without adequate compensation, ${ }^{141}$ Ms. Whitaker returned to her home believing that since she owned her home she had a right to reside there. Despite the fact that she owned her own home, the Columbia County Sheriff's Office ordered Ms. Whitaker to vacate her residence within seventy-two hours because it was within 1000 feet of a church with a child care center. ${ }^{142}$

Residency restrictions banishing undesirable individuals from our communities are supported by the fear and belief that individuals would undoubtedly reoffend. ${ }^{143}$ Sex offenders are banished to neighboring counties or states, and often corralled into poor neighborhoods and placed in boarding houses to reside solely with other sex offenders. ${ }^{144}$ Dr. Paul

sex offender registration requirements). The Doe court specifically addressed and dismissed the argument of banishment:

[W]hile banishment of course involves an extreme form of residency restriction, we ultimately do not accept the analogy between the traditional means of punishment and the lowa statute. Unlike banishment, $\$ 692 \mathrm{~A} .2 \mathrm{~A}$ restricts only where offenders may reside. It does not "expel" the offenders from their communities or prohibit them from accessing areas near schools or child care facilities for employment, to conduct commercial transactions, or for any purpose other than establishing a residence.

Doe, 405 F.3d at 719 .

137. Pre-Hearing Brief and Status Report at 9, Whitaker v. Perdue, No. 4:06-140-CC (N.D. Ga. Nov.11, 2008).

138. Fourth Amended Complaint - Class Action for Injunctive Release Jury Trial Demanded at 9, Whitaker v. Perdue, No. 4:06-cv-140-CC (N.D. Ga. Oct. 14, 2008) [hereinafter Amended Complaint]; Bill Rankin, Restricted by Registry No More: Lead Plaintiff Against Ga. Sex Offender Law Can Live Where She Wants to, Now, ATLANTA J.-CONST,, at B5 Sept. 18, 2010, available at http://www.schr.org/files/post/Wendy\%20AJC\%209\%2018\%2010.pdf.

139. Amended Complaint, supra note 138, at 9-10; Rankin, supra note 138, at B5.

140. 653 S.E.2d 740 (Ga. 2007).

141. Id. at 744-45 (explaining that the statute applied to a registered sex offender who purchased home in accordance with the statute but was later forced to move when a child care center opened within 1000 feet of the residence).

142. Rankin, supra note 138, at B1; see also Sarah Geraghty \& Melanie Velez, Bringing Transparency and Accountability to Criminal Justice Institutions in the South, 22 STAN. L. \& POL'Y REV. 455, 486, $487 \mathrm{n} .190$ (2011) (illustrating the general repercussions of the Georgia residency requirement after its passage and recounting the specific case of Wendy Whitaker).

143. See, e.g., Karen Sloan, Towns Fear an Influx of Offenders, OMAHA WORLD-HERALD,Oct.4, 2005, at $1 \mathrm{~A}$ (reporting on proposed local ordinances in Nebraska that would restrict sex offender residency, based on community fears of an influx of sex offenders from jurisdictions in which residency restrictions were already in place and a desire to protect children from such sex offenders); see also Saxer, supra note 123, at 1452 (noting that sex offenders are "undesirable" and there is a fear they will reoffend); Des Moines Zones Out Molesters, OMAHA WORLD- HERALD,Oct. 13, 2005, at 2B (reporting on a Des Moines ordinance that places residency restrictions on sex offenders).

144. Saxer, supra note 123, at 1399-40; Michael J. Duster, Out of Sight, Out of Mind: State Attempts 
Appelbaum clearly describes the fallout and potential harms in a 2008 column discussing community notification:

Given the consternation aroused by sex offenders, it can hardly be unexpected that the typical consequences of such disclosure are loss of housing, jobs, and friends. Yet these are just the kind of supports that can anchor a released offender in a community and reduce recidivism. Numerous reports have surfaced of offenders being threatened, harassed, and in rare cases killed after community notification. Suicide also has been reported. Perhaps most disturbing is the large number of states that fail to limit disclosures to predatory offenders, instead extending the process to everyone convicted of a sexually related offense. Swept up in this net are people who have committed noncontact crimes, such as exhibitionism or peeping, those whose only offense occurred as children, and persons who engaged in consensual sex with a somewhat younger girlfriend or boyfriend and were convicted of statutory rape. ${ }^{145}$

\section{Who's afraid of the big, bad wolf?}

We designed our community containment laws based on certain perceived truths: (1) that convicted sex offenders pose a greater danger to the public when they reside near places where children frequent, ${ }^{146}(2)$ that we can dispose of the problem by limiting their housing options in municipalities, ${ }^{147}$ and (3) that sex offenders coming out of prison or sex offender civil commitment have a high re-offense rate for contact sexual crimes. ${ }^{148}$ Yet studies conducted in a number of states do not confirm the

to Banish Sex Offenders, 53 DRAKE L. REV.711, 712 n.2(2005).

145. Paul Appelbaum, Law \& Psychiatry: Sex Offenders in the Community: Are Current Approaches Counterproductive?, 59 PSYCHIATRIC SERVICES352, 353 (2008) (footnotes omitted), available athttp:/ajp.psychiatryonline.org/data/Joumals/PSS/3843/08ps352.pdf.

146. Duster, supra note 144, at 714-16; Sloan, supra note 143, at 1A. But see HumaN Rights WatCH, supra note 91, at 103-04 (citing the lack of evidence supporting assertion that prohibiting offenders from living near children actually protects children from sexual violence); ASS'N FOR THE TREATMENT OF SeXuAl ABuSERS, FACTS ABOUT ADULT SEX OfFEnders (Apr. 5, 2010), available athttp://www.atsa.com/sexual-offender-residence-restrictions(stating that currently no studies show a relationship between residence,distancefromaschoolorchild-carefacility,andanincreasedlikelihood of recidivism).

147. See, e.g., Duster, supra note 144, at 717-18 (discussing attempts to restrict sex-offender housing options); Saxer, supra note 123, at 1452 (explaining generally the public policy behind residency requirements).

148. Consider the following discussion in Doe, 405 F.3d at 714-15:

There can be no doubt of a legislature's rationality in believing that "[s]ex offenders are a serious threat in this Nation," and that "[w] hen convicted sex offenders reenter society, they are much more likely than any other type of offender to be re-arrested for a new rape or sexual assault." Conn. Dep't of Pub. Safety, 538 U.S. at 4(alterations in original) (quoting McKune v. Lile, 536 U.S. 24, 32-33, (2002) (plurality opinion)). The only question remaining is whether, in view of a rationally perceived risk, the chosen residency restriction rationally advances the State's interest in protecting children.

Id. But see Hanson, supra, note33, at 63 (stating that according to a major study done by the Bureau of 
above listed beliefs:

- A New Jersey study sampling 268 sexual offenders found that (1) the strict residency restrictions caused a housing shortage for tracked offenders, ${ }^{149}$ and (2) offenders who targeted adults were more likely to live closer to children than those who offended against children. ${ }^{150}$

- In 2006, New York released a study analyzing 19,827 sex offenders and found that: (1) "[t]he rate for new sex offenses after one year in the community was 2 percent"; and (2) "[t]he cumulative rate increased to 3 percent after two years, 6 percent after five years, and 8 percent after eight years." 151

- A study in California followed ninety-three high-risk sex offenders and in 2006 issued results showing that after six years on the street, " 4.3 percent of these worst-of-the-worst offenders had committed new sex offenses." 152

- Alaska reported in 2007 that " 3 percent of sex offenders had committed a new sex crime in their first three years after release from prison." 153

- Tennessee "found that 4.7 percent of 504 sex offenders released from prison in 2001 were arrested for a new sex offense after three years. The sex crime recidivism rate was zero for offenders whose original crime was incest."I54

- Missouri tracked 3166 offenders between 1990 and $2002-$ covering a period before the enactment of residency restrictions and SORNA-and found that $12 \%$ had been rearrested for a new sex crime and of that $12 \%, 10 \%$ had been reconvicted. ${ }^{155}$

- A 2007 Minnesota Department of Corrections study "tracked [3166] sex offenders released from Minnesota prisons between 1990 and 2002" and found that "after an average of 8.4 years in the community, 10 percent had been convicted of a new sex offense. Those released in the beginning of the study period

Justice Statistics, when measured by re-arrest for the same type of crime, rapists had a relatively low rate of arrest for another rape (7.7\%) compared to larcenists (33.5\%), burglars (31.9\%), and drug offenders rearrested for drug offenses $(24.8 \%)$ ). Only murderers had a lower recidivism rate for the same crime than rapists. Allen J. Beck \& Bernard E. Shipley, U.S. DeP'T of Justice, Bureau of Justice Statistics, RECIDIVISM OF PRISONERS RELEASED IN 19835 (Apr. 1989), available at http://bjs.ojp.usdoj.gov/content/pub/pdf/rpr83.pdf).

149. Michael Chakewski \& Cynthia Calkins Mercado, An Evaluation of Sex Offender Residency Restriction Functioning in Town, County, and City-Wide Jurisdictions, 20 CRIM. JUST. POL'Y REV. 44, 45, 58 (2009).

150. Id. at $49-50$.

151. Chris Dornin, Facts and Fiction About Sex Offenders: Part 3 of a 3-Part Series, SENT'G \& JUST. REFORM ADVOC., July 2010 , at 6.

152. Id.

153. Id.

154. Id.

155. Id. 
were much more likely to reoffend within three years than those released later-17percent in 1990 as opposed to 3 percent in 2002. ${ }^{156}$

- West Virginia tracked 325 sex offenders from 2001-2003 and found that: (1) "[t]he recidivism rate for any return to prison, not just for sex crimes, was 9.5 percent"; (2) "six[individuals] returned for new sex related crimes," which included three crimes of failing to register; (3) "[t]he sex crime recidivism rate was slightly less than 2 percent"; and (4) "[o]nly 1 percent had an actual sex crime victim."157

Given the data that demonstrates the low recidivism rates for sex offenders (as compared with other criminals), ${ }^{158}$ it appears that bias and stigma surrounding the type of crime committed - sexual offenses-is what fuels our legislation. ${ }^{159}$ Thus we ignore and disregard current studies and instead act based on unfounded myths. ${ }^{160}$

\section{Do community notification and registration laws contribute to low reconviction and re-offense rates?}

Despite the substantial costs, little research has been conducted to examine whether such laws enhance community protection. ${ }^{161}$ In terms of community notification, it would appear that Megan's Law has failed to significantly reduce re-offending. ${ }^{162}$ The legislative assumption was that

156. $I d$.

157. Dornin, supra note 151 , at 6.

158. Sarah E. Agudo, Irregular Passion: The Unconstitutionality and Inefficacy of Sex Offender Residency Laws, 102 Nw. U. L. REV. 307, 308 n.1 (2008).

159. Id. at 308 .

160. Rob Freeman-Longo, Ctr. For Sex Offender Mgmt., Myths and Facts about SeX OFFENDERS, (Kristin Little \& Scott Matson, eds., 2000), available at http://www.csom.org/pubs/mythsfacts.html ("There are many misconceptions about sexual offenses, sexual offense victims, and sex offenders in our society. Much has been learned about these behaviors and populations in the past decade and this information is being used to develop more effective criminal justice interventions throughout the country. This document serves to inform citizens, policy makers, and practitioners about sex offenders and their victims, addressing the facts that underlie common assumptions both true and false in this rapidly evolving field.").

However, some statutes have created narrow laws that may prove to me more effective than others. See, e.g., WASH. REV. CODE ANN. $§ 9.94 A .030$ (West 2012) (providing that "high-risk offenders" cannot live within 880 feet of schools or daycare centers); N.Y. PENAL LAW $\$ 65.10(4-a)$ (McKinney Supp. 2009) (providing that serious offenders cannot enter school grounds or facilities caring for children).

161. Agudo, supra note 158, at 309, 339; Jill S. Levenson \& Leo P. Cotter, The Impact of Sex Offender Residence Restrictions: 1,000 Feet From Danger or One Step From Absurd?, 49 INT'L. J. OFFENDER THERAPY\& COMP. CRIMINOLOGY 168, 169 (2005) [hereinafter Impact of Sex Offender Restrictions].

162. See Victoria Simpson Beck et al., Community Response to Sex Offenders,32 J. PSYCHIATRY \& L.141, 165 (2004) ("Finally, some have argued that the stigmatizing and anti-therapeutic effects of notification may increase the risks for recidivism."); Zgobra, supra note 18, at 39 (noting that although there has been a downward trend in sex-offender recidivism, this trend began before the passage of the Megan's Law, and therefore the decline cannot be "solely attributed" to the law). 
community notification would deter new offenses and citizens would take protective measures against sex offenders; "[e]xactly what action is expected is not clear." 163 Unfortunately, these strategies are based on evidence that is anecdotal or plain conjecture. ${ }^{164}$ As noted above, the efficacy and cost of Megan's Law has been thoroughly examined, ${ }^{165}$ and comparing constitutional challenges, ${ }^{166}$ some courts have begun to question the intent of the legislation and render opinions finding certain regulations unconstitutional. ${ }^{167}$ The U.S. Supreme Court has been reluctant to review many of the decisions regarding community notification and registration, ${ }^{168}$ but, in 2003, the Court issued three separate decisions on the retroactive application of SVP laws. Of the three cases, Smith v. Doe $e^{169}$ and Connecticut Department of Public Safety v. Doe ${ }^{170}$ upheld the retroactive application of these laws and rejected arguments of ex post facto violations. ${ }^{171}$ The Court found both statutes to be non-punitive, and gave little weight to the consequential stigma and potential negative impact of these laws. ${ }^{172}$ Only Stogner $v$. California ${ }^{173}$ held that application of the

163. Beck et al., supra note 162 , at 142 .

164. Rice \& Harris, supra note 52, at 102 (noting that "treatment effectiveness will be grossly overestimated in studies if treatment refusers and dropouts are ignored"); Simon, supra note9, at 149-50 (describing the disjuncture between legislation and the empirical realities of sex crimes).

165. Zgoba et al., supra note18.

166. See generally Mann v. State, 603 S.E.2d 283, 285 (Ga. 2004) (finding a residency statute not to be in violation of the Constitution's proscription against ex post facto laws); Thompson v. State, 603 S.E.2d 233, 234 (Ga. 2004) (finding a statute preventing a person required to register as a sex offender from living within 1000 feet of any area where minors congregate not to be in violation of ex post facto doctrine); Denson v. State, 600 S.E.2d 645, 646 (Ga. Ct. App. 2004) (holding that statute was not an unconstitutional ex post facto law as applied); People v. Leroy, 828 N.E.2d 769, 776-78 (11l. App. Ct. 2005) (finding that residency restriction was not in violation of the constitutional right to due process); State v. Seering, 701 N.W.2d 655, 670 (lowa 2005) (holding that statute did not violate substantive due process or ex post facto clause); Weems v. Little Rock Police Dep't, 453 F.3d 1010, 1016-20 (8th Cir. 2006)(finding that residency restriction did not violate constitutional right to travel, ex post facto law, or substantive due process).

167. The appeals court in Mann determined that an unconstitutional taking had occurred where an offender was forced to move from his home after a child-care facility opened within 1000 feet of his property. 653 S.E.2d at 741 . In rendering its decision, the court considered the economic hardship that occurred as a result of the taking as well as the interference with an individual's reasonable investmentbacked expectation when purchasing property for a private residence. Id.at 744 . The court additionally assessed the statute and found that it effectively empowered private third parties with the state's police power. Id. at 745.In 2009, Indiana's Supreme Court, in State v. Pollard, 908 N.E.2d 1145 (Ind. 2009) held that the residency restriction "violate[d] the prohibition on ex post facto laws . . because it impose[d] burdens that ha[d] the effect of adding punishment beyond that which could have been imposed [at the time the] crime was committed." $I d$. at 1154.

168. Charles Scott \& Trent Holmberg, Castration of Sex Offenders: Prisoners' Rights Versus Public Safety, 31 J. AM. ACAD. PSYCHIATRY L. 502, 508 (2003).

169. 538 U.S. $84,105-06$ (2003) (holding that the retroactive application of the registration and notification requirements of the Alaska SVP statute did not violate the ex post facto clause).

170. 538 U.S. 1, 7 (2003) (finding that even if the public notification procedures implicated a liberty interest, sex offenders were not entitled to a hearing to determine whether they were currently dangerous before their inclusion in the registry).

171. Smith, 538 U.S. at 105-06 (finding no ex post facto violations); Conn. Dep't of Pub. Safety, 538 U.S. at 2 (same).

172. See Smith, 538 U.S. at 98 ("Any initial resemblance [of Alaska's compulsory registration] to 
California law, which extended the time to prosecute sexual crimes, was unconstitutionally ex post facto as applied to Stogner. ${ }^{174}$

A number of scholarly articles have found that the strict ordinances banning offenders from living in numerous areas within the state result in a situation that is the modern equivalent of the medieval sanction of banishment. ${ }^{175}$ Scholars have proposed that residency restriction laws are, in fact, counterproductive in their strict application, and can result in homelessness and isolation; they have the opposite effect of promoting safe communities by actually heightening the risk of re-offense. ${ }^{176}$ Such strict application of these laws-combined with their effects of isolation and humiliation-can provoke feelings of hopelessness, and unworthiness, and can cause both lack of dignity and feelings of being "less than human" among sex offenders. ${ }^{177}$ Hardships placed on individuals in the community

early punishments is, however, misleading .... Even punishments that lacked the corporal component, such as public shaming, humiliation, and banishment, involved more than the dissemination of information.").

The Court in Conn. Dep't of Pub. Safety,538 U.S. at 6-7, relied on Paul v. Davis, 424 U.S. 693 (1976), which had held that mere injury to reputation, even if defamatory, does not constitute the deprivation of a liberty interest. The Court concluded that:

In short, even if respondent could prove that he is not likely to be currently dangerous, Connecticut has decided that the registry information of all sex offenders-currently dangerous or not-must be publicly disclosed. Unless respondent can show that that substantive rule of law is defective (by conflicting with a provision of the Constitution), any hearing on current dangerousness is a bootless exercise.

Conn. Dep't of Pub. Safety, 538 U.S. at 7-8.

173. 539 U.S. 607 (2003).

174. Id . at 609.

175. See Yung, supra note 124, at 103-04, 106-07 (discussing the concept of banishment for sex offenders subjected to harsh residency restrictions); see also ZEVITZ \& FARKAS, supra note 93, at 9-11 (discussing the challenges faced in placing sex offenders in housing in residential areas postincarceration); Saxer, supra note 123, at 1405-11 (explaining how sex offender residency restrictions "banish" sex offenders from living in certain areas or communities); Sex Offenders Living Under Miami Bridge, N.Y. TIMES, Apr. 8, 2007, www.nytimes.com/2007/04/08/us/08bridge.html (describing a group of sex offenders forced to live under a bridge because they could not obtain housing in accordance with a Miami-Dade county ordinance limiting where sex offenders can live).

176. See HUMAN RIGHTS WATCH, supra note 91, at 9-10 (stating that transiency and lack of habilitation has caused lowa officials to lose track of offenders); Tewksbury, supra note 96, at 78-79 (stating that the use of sex-offender registries may lead to social withdrawal and greater anxiety and stress for sex offenders; this process, for some sex offenders, can be a precursor to re-offending); Meloy et al., supra note 6, at 438 (stating that the shaming of offenders increases deviant behavior); Stephanie Chen, After Prison, Few Places for Sex Offenders to Live, WALL ST. J., Feb. 19, 2009, at A16 (expressing that residency restrictions may destabilize past offenders); Yung, supra note 124, at 105 (describing the social ostracization and isolation that offenders are faced with); Jeffrey Koffman, Sex Offenders Live in Village Under Miami Bridge, ABC NIGHTLINE (Sept. 3, 2009), http://abcnews.go.com/Nightline/sex-offenders-live-miami-bridge/story?id=8420696\#.UEfJe45Dz7J

(identifying past sex offenders who now live as pariahs under the Julia Tuttle Causeway in Miami); Saxer, supra note 123, at 1400 (stating that concentration of offenders in poor neighborhoods may result in adverse community impacts).

177. See Fred Cohen, From the Editor: Sex Offender Registration Laws; Constitutional and Policy Issues, 31 CRIM. L. BULL. 151, 153 (1995) (explaining that the implementation of "Megan's Law" generates such public stigma and secial ostracism as to be viewed as punitive); Abril R. Bedarf, 
serve to break down protective measures and increase stressors, two of the major catalysts claimed by experts to fuel relapse. ${ }^{178}$ The psychological stress from "isolation, disempowerment, shame, depression, anxiety [and] lack of social supports . . . can trigger some sex offenders to relapse."179 Clearly, the end result of our efforts serves no benefit to the offender or the community.

There needs to be a shift in our conceptualization and inevitable interaction with this population in order to be successful in combating the inherent problems of sex-offender punishments. Specifically, we need to confront and analyze our fears and construct solutions that account for the human rights of all persons. Our approach to change must begin by examining these issues through the lens and application of therapeutic jurisprudence.

\section{THROUGH THE LENS OF THERAPEUTIC JURISPRUDENCE}

\section{A. Therapeutic jurisprudence: An overview}

One of the most important legal theoretical developments of the past two decades has been the creation and dynamic growth of therapeutic jurisprudence ("TJ"). ${ }^{180} \mathrm{TJ}$ presents a new model for assessing the impact of

Examining Sex Offender Community Notification Laws, 83 CALIF. L. REV. 885, 910 (1995) (explaining that community notification jeopardizes an offender's ability to reintegrate into society and lead a productive life); ZEVITZ \& FARKAS, supra note 93, at 9 (finding that seventy-seven percent of interviewed sex offenders told of being humiliated in their daily lives and ostracized by neighbors and lifelong acquaintances due to expanded notification actions); see also Michael L. Perlin, "Dignity Was the First to Leave": Godinez v. Moran, Colin Ferguson, and the Trial of Mentally Disabled Criminal Defendants, 14 BEHAV. SCI. \& L. 61, 75 (1996) (discussing the constitutional significance of dignity in the criminal trial process); MICHAEL L. PERLIN, A PRESCRIPTION FOR DIGNITY: RETHINKING CRIMINAL JUSTICE AND MENTAL DiSABILITY LAW (forthcoming 2013).

178. Levenson \& Cotter, supra note 105 , at 62.

179. Impact of Sex Offender Restrictions, supra note 161 , at 169 (citation omitted).

180. See, e.g., David B. WeXler, Therapeutic Jurisprudence: The LaW as a Therapeutic AGENT3-4, 19-20 (1990) (discussing TJ's origins in mental health law and the general growth of applying the social sciences to legal scholarship); DAVID B. WEXLER \& BRUCE J. WINICK, LAW IN A THERAPEUTIC KEY: RECENT DEVElopmENTS IN THERAPEUTIC JURISPRUDENCE, at xviii-xix (1996) (describing the growing body of academic literature on TJ arising from the fields of law, psychology, psychiatry, criminology, and philosophy, as well as discussing TJ's evolution and growing influence); BRuCE J. WINICK, CIVIL COMMITMENT: A THERAPEUTIC JURISPRUdENCE MODEL 7-8 (2005) (discussing TJ's domestic and international growth, noting that TJ "evolved out of the work of [David B.] Wexler and [Bruce] Winick in mental health law, and has emerged as one of the most important influences on the field. It has since spread across the legal landscape, emerging as a mental health approach to law generally") (footnotes omitted); David B. Wexler, Two Decades of Therapeutic Jurisprudence, 24 TOURO L. REV. 17, 17(2008) (discussing the growth of therapeutic jurisprudence from its birth in mental health law to its effects on the "entire legal spectrum"); 1 MICHAEL L. PERLIN, MENTAL DiSABILITY LaW: Civil AND CRIMINal $\S 2 \mathrm{D}-3$, at 534-41 (2d ed. 1998) (providing a discussion of the relatively nascent yet growing $\mathrm{TJ}$ approach and the various areas of law it has been applied to over the years, as well as the new areas that scholars are beginning to explore through the therapeutic jurisprudence perspective). Wexler first used the term in a paper he presented to the National Institute of Mental Health (NIMH) in 1987. See David B. Wexler, The Development of Therapeutic Jurisprudence: From Theory to Practice, 68 REV. JUR. U.P.R. 691, 693 (1999) (describing Wexler's 
case law and legislation, recognizing that, as a therapeutic agent, the law can have therapeutic or anti-therapeutic consequences. ${ }^{181}$ The ultimate aim of $\mathrm{TJ}$ is to determine whether legal rules, procedures, and lawyer roles can or should be reshaped to enhance their therapeutic potential while not subordinating due process principles. ${ }^{182}$ There is an inherent tension in this inquiry, but David Wexler clearly identifies how it must be resolved: the law's use of "mental health information to improve therapeutic functioning ... [cannot] imping[e] upon justice concerns." 183 As one of us (MLP) has written elsewhere, "an inquiry into therapeutic outcomes does not mean that therapeutic concerns 'trump' civil rights and civil liberties." 184

TJ, which is a descendant of legal realism, "asks us to look at law as it actually impacts people's lives" 185 and focuses on the law's influence "on emotional life and psychological well-being."186 It "suggests that law should value psychological health, should strive to avoid imposing anti-therapeutic consequences whenever possible, and when consistent with other values served by law, should attempt to bring about healing and wellness."187By way of example, "[t]herapeutic jurisprudence aims to offer social science evidence that limits the use of the incompetency label by narrowly defining its use and minimizing its psychological and social disadvantage."188

work on a paper for the NIMH workshop that first made the "therapeutic jurisprudence perspective explicit"); David B. Wexler, Putting Mental Health into Mental Health Law: Therapeutic Jurisprudence, 16 L. \& HUM. BEHAV. 27, 33 (1992) (explaining that Wexler's interest in TJ "jelled" in 1987, culminating in a paper he wrote for a NIMH workshop).

181. See Michael L. Perlin, "His Brain Has Been Mismanaged with Great Skill": How Will Jurors Respond to Neuroimaging Testimony in Insanity Defense Cases?, 42 AKRON L. REV. 885, 912 (2009) ("[TJ] presents a new model by which we can assess the ultimate impact of case law and legislation that affects mentally disabled individuals . . . by studying the role of the law as a therapeutic agent."). See Kate Diesfeld \& Ian Freckelton, Mental Health Law and Therapeutic Jurisprudence, inDiSPUTES AND Dilemmas IN Health LAw 91 (Ian Freckelton \& K. Peterson eds., 2006), for a transnational perspective on TJ.

182. Michael L. Perlin, "And My Best Friend, My Doctor/Won't Even Say What It Is I've Got": The Role and Significance of Counsel in Right to Refuse Treatment Cases, 42 SAN DIEGo L. REV. 735, 751 (2005); Michael L. Perlin, "Everybody Is Making Love/Or Else Expecting Rain": Considering the Sexual Autonomy Rights of Persons Institutionalized Because of Mental Disability in Forensic Hospitals and in Asia,83 WASH. U. L. REv. 481,510 n.139 (2008); see also Michael L. Perlin, "You Have Discussed Lepers and Crooks": Sanism in Clinical Teaching, 9 CLINICAL L. REV. 683, 727-28 (2003) (discussing the benefits of applying $\mathrm{TJ}$ to clinical teaching).

183. David B. Wexler, Therapeutic Jurisprudence and Changing Concepts of Legal Scholarship, 11 BEHAV. SCI. \& L. 17, 21 (1993).

184. Michael L. Perlin, A Law of Healing, 68 U. CIN. L. REv. 407, 412 (2000); Michael L. Perlin, "Where the Winds Hit Heavy on the Borderline": Mental Disability Law, Theory and Practice, "Us" and "Them", 31 LOY. L.A. L. REV. 775, 782 (1998).

185. Bruce J. Winick, Foreword: Therapeutic Jurisprudence Perspectives on Dealing with Victims of Crime, 33 Nova L. REV. 535, 535 (2009) (footnote omitted).

186. David B. Wexler, Practicing Therapeutic Jurisprudence: Psycholegal Soft Spots and Strategies, in Practicing Therapeutic Jurisprudence: Law as a helpng Profession 45, 45 (Daniel P. Stolle, et al., eds. 2000) [hereinafter STOLLEET AL.].

187. Bruce Winick, A Therapeutic Jurisprudence Model for Civil Commitment, in INvOLUNTARY Detention aND THERAPEUTIC JURISPRUdenCE: INTERNATIONAL PERSPECTIVES ON CivIL COMMITMENT 23, 26 (Kate Diesfeld \& lan Freckelton eds., 2003).

188. Claire B. Steinberger, Persistence and Change in the Life of the Law: Can Therapeutic 
In recent years, scholars have considered a vast range of topics through a therapeutic jurisprudence lens, including, but not limited to, all aspects of mental disability law, domestic relations law, criminal law and procedure, employment law, gay rights law, and tort law. ${ }^{189}$ As Ian Freckelton has noted, "it is a tool for gaining a new and distinctive perspective utilizing socio-psychological insights into the law and its applications." 190 It is also part of a growing, comprehensive movement in the law towards establishing more humane and psychologically optimal ways of handling legal issues collaboratively, creatively, and respectfully. ${ }^{191}$ These alternative approaches optimize the psychological well-being of individuals, relationships, and communities dealing with a legal matter, and acknowledge concerns beyond strict legal rights, duties, and obligations. ${ }^{192}$ In its aim to use the law to empower individuals, enhance rights, and promote well being, therapeutic jurisprudence has been described as "a seachange in ethical thinking about the role of law ... a movement towards a more distinctly relational approach to the practice of law . . . which emphasise[s] psychological wellness over adversarial triumphalism."193 That is, TJ supports an ethic of care. ${ }^{194}$

Jurisprudence Make A Difference?, 27 L. \& PSYCHOL. REV. 55, 65 (2003) (footnote omitted). The most thoughtful, sympathetic critique of TJ remains Christopher Slobogin, Therapeutic Jurispridence: Five Dilemmas to Ponder, 1 PSyCHOL. PUB. POL'Y \& L. 193 (1995). See David B. Wexler, Reflections on the Scope of Therapeutic Jurisprudence, 1 PSYCHOL. PUB. POL'Y \& L. 220, 220 n.2 (1995) (describing Slobogin's work as "an excellent assessment and thoughtful critique" of TJ).

189. Michael L. Perlin, "Things Have Changed:" Looking at Non-Institutional Mental Disability Law Through the Sanism Filter, 46 N.Y.L. SCH. L. REV. 535, 537-38, 544-45 (2002-03).

190. Ian Freckelton, Therapeutic Jurisprudence Misunderstood and Misrepresented: The Price and Risks of Influence, 30 T. JEFFERSON L. REV. 575, 576 (2008).

191. Susan Daicoff, The Role of Therapeutic Jurisprudence within the Comprehensive Law Movement, in STOLLE ET AL, supra note 186, at 465.

192. E.g., Freckelton, supra note 190, at 575-80 (providing a lengthy overview of TJ's utility and describing $\mathrm{TJ}$ as an approach to the law whereby beneficial and holistic societal outcomes for both the individual(s) directly involved and society as a whole are meant to be maximized while the law's therapeutic capacity to do both harm and good are realized).

193. Warren Brookbanks, Therapeutic Jurisprudence: Conceiving an Ethical Framework, 8 J.L. \& MED. 328, 329 (2001) (footnote omitted).

194. See, e.g., Gregory Baker, Do You Hear the Knocking at the Door? A "Therapeutic" Approach to Enriching Clinical Legal Education Comes Calling, 28 WHITTIER L. REV. 379, 385 (2006) (noting that the "TJ approach ... focuses on such things as improving interpersonal skills, practicing with a true ethic of care, and viewing the law as a 'helping profession'"); Brookbanks, supra note 193, at 329-30 (presenting the thesis that TJ, with a significant focus on an ethic of care "redefines the role of law as a means of problem-solving and offers an alternative approach to legal practice based on a model which encourages relational intimacy, self-awareness, conciliation and restoration"); David B. Wexler, Not Such a Party Pooper: An Attempt to Accommodate (Many of) Professor Quinn's Concerns About Therapeutic Jurisprudence Criminal Defense Lawyering, 48 B.C. L. REV. 597, 599 (2007) (concluding that a TJ approach to criminal law "will encourage criminal lawyers to practice explicitly and systematically with an 'ethic of care' and 'psychological sensitivity"'); Bruce J. Winick \& David B. Wexler, The Use of Therapeutic Jurisprudence in Law School Clinical Education: Transforming the Criminal Law Clinic, 13 CLINICAL L. REV. 605, 605-07 (2006) (describing the application of TJ as calling for "an ethic of care and heightened interpersonal skills" amongst attomeys in order to best assist their clients as "therapeutic agents"). 
One of the central principles of $\mathrm{TJ}$ is a commitment to dignity. ${ }^{195}$ Professor Amy Ronner describes the "three Vs": voice, validation and voluntary participation, arguing:

What "the three Vs" commend is pretty basic: litigants must have a sense of voice or a chance to tell their story to a decision maker. If that litigant feels that the tribunal has genuinely listened to, heard, and taken seriously the litigant's story, the litigant feels a sense of validation. When litigants emerge from a legal proceeding with a sense of voice and validation, they are more at peace with the outcome. Voice and validation create a sense of voluntary participation, one in which the litigant experiences the proceeding as less coercive. Specifically, the feeling on the part of litigants that they voluntarily partook in the very process that engendered the end result or the very judicial pronunciation that affects their own lives can initiate healing and bring about improved behavior in the future. In general, human beings prosper when they feel that they are making, or at least participating in, their own decisions. ${ }^{196}$

\section{B. Do sex offender laws and judicial proceedings promote a vision that is consonant with the principles of "voice, validation, and voluntary participation" proposed by Professor Ronner?}

The origins and development of sex offender law have had a profoundly anti-therapeutic effect. This is so for multiple reasons:

- The current universe of sex offender laws presumes a uniform type of offender with uniform reasons for offending with relatively static strengths and weaknesses. ${ }^{197}$ Nothing in the literature supports this assumption.

- The current universe of sex offender laws presumes that everyone is a recidivist. ${ }^{198}$ According to a U.S. Bureau of

195. See, e.g., Steinberger, supra note 188, at 64 (describing TJ's focus on psychological and social outcomes as including "feelings of dignity and self-worth"); Amy D. Ronner, The Learned-Helpless Lawyer: Clinical Legal Education and Therapeutic Jurisprudence as Antidotes to Bartleby Syndrome, 24 TOURO L. REV. 601, 627-28 (2008) (describing evidence suggesting "that when individuals feel the system has treated them with fairness, respect, and dignity, their behavior improves and they tend to become healthier in their everyday lives") (footnote omitted).

196. Amy D. Ronner, Songs of Validation, Voice, and Voluntary Participation: Therapeutic Jurisprudence, Miranda and Juveniles, 71 U. CIN. L. REV. 89, 94-95 (2002) (footnotes omitted). See generally, AMY D. RONNER, LAW, LITERATURE, AND THERAPEUTIC JURISPRUDENCE23-24 (2010) (discussing the importance, positive effects, as well as interaction of "the three Vs" and noting that voice leads to validation, which, when combined with voice, tends to foster a sense of voluntary participation in the legal system).

197. Chrysanthi S. Leon, Sex Fiends, Perverts, and Pedophiles: Understanding Sex Crime POLICY IN AMERICA 181 (2011); Paul Noroian \& Fabian M. Saleh, Residency Restrictions for Convicted Offenders, 34 J. AM. ACAD. PSYCHIATRY \& L. 422, 424 (2006).

198. See Benjamin Radford, Predator Panic: Reality Check on Sex Offenders, LIVE SCIENCE (May 16, 2006, 4:55 AM), http:/www.livescience.com/776-predator-panic-reality-check-sex-offenders.html ("The high recidivism rate among sex offenders is repeated so often that it is usually accepted as truth, but in fact recent studies show that the recidivism rates for sex offenses is not unusually high."). $C f$. Howard N. SNYDER, BLREAL OF JUSTICE STATISTICS, SEXLAL ASSAULT OF YOUNG CHILDREN AS 
Justice Statistics study ("Recidivism of Sex Offenders Released from Prison in 1994"), just five percent of sex offenders followed for three years after their release from prison in 1994 were arrested for another sex crime. A study released in 2003 by the [U.S. Bureau of Justice Statistics] found that within three years, 3.3[\%] [or 141 of 4295$]^{199}$ of the released child molesters were arrested again for committing another sex crime against a child. Three to five percent is hardly a high repeat offender rate. In the largest and most comprehensive study ever done of prison recidivism, the Justice Department found that sex offenders were in fact less likely to reoffend than other criminals. The 2003 study of nearly 10,000 men convicted of rape, sexual assault, and child molestation found that sex offenders had a re-arrest rate 25 percent lower than for all other criminals. Part of the reason is that serial sex offenders- those who pose the greatest threatrarely get released from prison, and the ones who do are unlikely to re-offend. ${ }^{200}$

- The current universe of sex offender laws presumes that the most likely sex-offense scenario is what is awkwardly often called "stranger rape."'201 Statistics, though, indicate that the majority of women who have been raped know their assailant. A 1998 National Violence Against Women Survey revealed that among those women who reported being raped, $59 \%$ were victimized by a current or former husband, live-in partner, or date. ${ }^{202}$ Also, a Bureau of Justice Statistics study found that nearly three out of four rape or sexual assault victimizations involved a single offender with whom the victim had a prior relationship, such as a family member, intimate, or acquaintance..$^{203}$ In the cases of child victims, there is no question that relatives, friends, baby-sitters, persons in

REPORTED TO LAW ENFORCEMENT: VICTIM, INCIDENT, AND OFFENDER CHARACTERISTICS 1 (2000), available at http://bjs.ojp.usdoj.gov/content/pub/pdf/saycrle.pdf (arguing that although "a few highly publicized incidents" of sexual assaults have put the danger of sex crimes in the forefront of law enforcement and the publics' minds, "there is little empirically-based information on these crimes").

199. Bialik, supra note 112.

200. Radford, supra note198 (citations omitted).

201. See, e.g., id. (asserting that stranger rape is very rare, and that most child sexual abuse is committed by a person whom the child knows).

202. Patricia TJaden \& Nancy Thoennes, Nat'L Inst. of Justice \& Ctrs. for Disease CONTROL \& PREVENTION, STALKING IN AMERICA: FINDINGS FROM THE NATIONAL ViolenCE AGaINST WOMEN SURVEY 6 (1998).

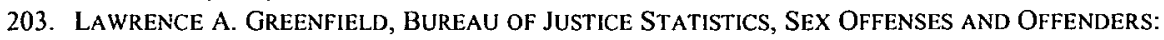
AN ANALYSIS OF DATA ON RAPE AND SEXUAL ASSAULT 4 (1997), available at http://bjs.ojp.usdoj.gov/content/pub/pdf/SOO.PDF; see also LAWRENCE A. GREENFIELD ET AL., BUREAU OF JUSTICE STATISTICS, VIOLENCE By INTIMATES: ANALYSIS OF DATA ON CRIMES by CURRENT OR FORMER SPOUSES, BOYFRIENDS, AND GIRLFRIENDS 4 (1998), available at http://bjs.ojp.usdoj.gov/content/pub/pdf/vi.pdf(supporting assertion that intimates account for a large percentage of the violence against women). 
positions of authority over the child, or persons who supervise children are more likely than strangers to commit a sexual assault. ${ }^{204}$

- The current universe of sex offender laws presumes that registration law and community "banishment" law minimizes re-offending. ${ }^{205}$ There is no evidence that such laws are effective in reducing re-offending, ${ }^{206}$ or that they provide incentives for sex offenders to engage in treatment in the community or demonstrate a pro-social lifestyle. ${ }^{207}$

- The current universe of sex-offender laws ignores the multiple ways that the court process and the roles played by defense counsel and the prosecution-as is done currently-support cognitive distortions that can be used by sex offenders as ways of justifying sexual offending ${ }^{208}$ and, by emphasizing punishment, retribution, and incapacitation, often provide disincentives for sex offenders to undergo treatment. ${ }^{209}$ Similarly, "the confrontational adjudicative process of traditional courts encourages advocacy of innocence, discourages acceptance of responsibility, and influences [subsequent acceptance] of treatment once sentenced."'210

On the other hand, scholars have crafted potential ameliorative suggestions using $\mathrm{TJ}$ tools and methods. One of the co-authors (HEC) has proposed a TJ approach in the form of Sex-Offender Courts for sentencing. ${ }^{211}$ These courts would employ a non-confrontational system in order to encourage acceptance of responsibility, to allow high-risk offenders to be reevaluated throughout the terms of their sentence, to provide positive reinforcement for changes in behavior and attitude during treatment, to

204. See SNYDER, supra note 198, at 9-10, 13 (explaining that offenders in child sexual assaults are very rarely strangers to the victim).

205. Cf. Baker, 2006 U.S. Dist. LEXIS 67925, at $\$ 11-14$ (finding that a Georgia state law requiring registered sex offenders to live at least 1000 feet from a child care facility or school was constitutional, but acknowledging that if the law was more restrictive, it could be analogous to banishment).

206. Birgden \& Cucolo, supra note 59, at 301 (arguing that registration laws do not decrease reoffense rates); see Rice \& Harris, supronote52, at 109 ("Simply put, the effectiveness of adult sex offender treatment has yet to be demonstrated.").

207. Astrid Birgden, Therapeutic Jurisprudence and Sex Offenders: A Psycho-legal Approach to Protection, 16 Sexual ABuse: J. Res. \& Treatment 351, 355 (2004).

208. Id. at 358 .

209. William Edwards \& Christopher Hensley, Contextualizing Sex Offender Management Legislation and Policy: Evaluating the Problem of Latent Consequences in Community Notification Laws, 45 INT'L. J. OfFENDER THERAPY \& COMP. CRIMINOLOGY 83, 94-95 (2001).

210. Birgden \& Cucolo, supra note 59, at 306; see also Birgden, supra note 207, at 357 (arguing that offenders will only accept responsibility for their actions if legal actors take a motivational approach towards the offender).

211. Cucolo, supra note 39; see, e.g., Pennsylvania to Be the Third State with Dedicated Sex Offender Court, Thomson REuters NEwS \& INSIGHT (May 8, 2011), http://newsandinsight.thomsonreuters.com/Legal/News/2011/05 -

_May/Pennsylvania_to_be_third_state_with_dedicated_sex_offender_court/ (discussing sex-offender courts in Pennsylvania and noting that New York and Ohio have similar regimes). 
allow for early release with intensive parole supervision, and to sanction the placement of low-risk offenders in the community for monitoring and treatment. ${ }^{212}$ In addition, reforms need to extend to the correctional system and to the monitoring of the offender in the community. ${ }^{213}$

\section{Why has the legal system been reluctant to adopt TJ principles in sex} offender case law and legislation?

We can think of several overlapping reasons for why the legal system has resisted TJ principles.

First, there is the fear of being seen as "soft on crime," imperiling the judge's re-election chances. ${ }^{214}$ The literature is replete with studies of political campaigns--many of which were successful-that turned on this precise issue. ${ }^{215}$

Next, judges are traditionally adverse to endorsing or utilizing any intervention that might be perceived as being "touchy-feely." 216 In this context, New York Chief Judge Jonathan Lippman has stated, "[s]ome see the specter of well-meaning but misguided 'touchy-feely' judges intent on pursuing rehabilitation and their own personal conceptions of social justice at the expense of punishment and accountability."217

Third, like the general public, judges have, by and large, bought into myths about sex offenses and sex offenders discussed earlier, and the perceived positive impact of sex-offender laws on the general public. ${ }^{218}$ Thus, even though procedural fairness should be the touchstone of the judicial process, ${ }^{219}$ it is very difficult to achieve this in sex-offender cases where the public-and many judges-reject the notion that this cohort of offenders even deserves" procedural fairness," in spite of the fact that such fairness inevitably increases compliance with court orders. ${ }^{220}$

212. John Q. La Fond \& Bruce J. Winick, Sex Offender Reentry Courts: A Proposal for Managing the Risk of Returning Sex Offenders to the Community, 34 SETON HALL L. REV. 1173, 1196-97 (2004).

213. Id. at 1194 .

214. Paul Carrington, Public Funding of Judicial Campaigns: The North Carolina Experience and the Activism of the Supreme Court, 89 N.C. L. REV. 1965, 1990 (2011).

215. See id. at $1989-90$ (discussing the California Supreme Court election of 1986 that led to the defeat of Chief Justice Rose Bird and two other associate justices perceived in this way); John Blume\& Theodore Eisenberg, Judicial Politics, Death Penalty Appeals, and Case Selection: An Empirical Study, 72 S. CAL. L. REv. 465, 470-72 (1999) (discussing political campaigns aimed at ousting individual judges for being "soft on crime").

216. See Jonathan Lippman, Achieving Better Outcomes for Litigants in the New York State Courts, 34 FORDHAM URB. L.J. 813, 830 (2007).

217. $I d$.

218. See, e.g., Winick, supra note 13, at 552 (discussing the "small" likelihood of a judge ever overruling a prosecutor's discretionary determination in such cases).

219. See, e.g., Kevin Burke \& Steve Leben, Procedural Fairness: A Key Ingredient in Public Satisfaction, 44 CT. REV. 4, 6 (2007-08) ("Procedural faimess matters to every litigant who appears before a judge.").

220. See, e.g., Raymond Paternoster et al., Do Fair Procedures Matter?: The Effect of Procedural Justice on Spouse Assault, 31 LAW \& SOC'Y REV. 163, 165 (1997) (stating that "[i]n speculating as to why an adherence to fair procedures by authorities would lead to conformity by subjects, some . . . adopt the instrumentalist position that fair procedures will facilitate fair outcomes. It is the securing of 
Fourth, judges have a deep need to convince themselves that the "system works." 221 Judges typically express great faith in the adversary system, ${ }^{222}$ and their opinions typically express a deep-seated "attachment to commonly held beliefs," 223 notwithstanding the reality that "subconscious influences can cloud their decisions and impede their legal reasoning," even when "they desire to render a 'fair' decision." 224

To a great extent, this all flows from the pernicious impact of heuristic thinking and the meretricious impact of a false "ordinary common sense" ("OCS") on judicial decision-making. ${ }^{225}$ OCS is self-referential and nonreflective ("I see it that way, therefore everyone sees it that way; I see it that way, therefore that's the way it is"). ${ }^{226}$ In criminal procedure, by way of example, "OCS presupposes two self-evident truths: 1) everyone knows how to assess an individual's behavior, and 2) everyone knows when to blame someone for doing wrong."227 Heuristics are "simplifying cognitive devices that frequently lead to ... systematically erroneous decisions through ignoring or misusing rationally useful information."228 Professor Terry Maroney explains:

[J]udges are prone to the same heuristics and biases as are other human beings, but also that these factors influence their judgingand not always for the better. For example, judges overweight small risks and underweight large ones, just as most people do. They also are prone to anchoring, hindsight, and egocentric biases, and they rely on ostensibly nonrational decisional tools such as intuition. ${ }^{229}$

And Professor Eden King notes that:

[A]ttitudinal forces may be coupled with cognitive biases that lead

favorable outcomes which then secures compliance").

221. See, e.g., Burke \& Leben, supra note 219 , at 21 (discussing ways in which judges can improve the public's satisfaction with the court system in the United States).

222. Daniel W. Shuman et al., An Empirical Examination of the Use of Expert Witnesses in the Courts-Part II: A Three City Study, 34 JuRIMETRICs J. 193, 207 (1994) (reporting on survey results).

223. Lode Walgrave, Restoration in Youth Justice, 31 CRIME \& JUST. 543, 547(2004).

224. Evan R. Seamone, Understanding the Person Beneath the Robe: Practical Methods for Neutralizing Harmful Judicial Biases, 42 WILLAMETTE L. REV. 1, 3 (2006) ("Consequently, in many circumstances, for judges to be fair, they must be capable of identifying subconscious influences on their behavior and they must neutralize the effects of such impulses.").

225. See generally Michael L. Perlin, The hidden Prejudice: Mental Disability on Trial 16(2000) (discussing OCS as an "unconscious animator of legal decision making").

226. Michael L. Perlin, She Breaks Just Like a Little Girl: Neonaticide, The Insanity Defense, and the Irrelevance of Ordinary Common Sense, 10 WM. \& MARY J. WOMEN \& L. 1, 8 (2003).

227. Id.

228. Michael L. Perlin, "They Keep It All Hid": The Ghettoization of Mental Disability Law and Its Implications for Legal Education, 54 ST. LoUIS U. L.J. 857, 875 (2010) (citing Michael L. Perlin, Fatal Assumption: A Critical Evaluation of the Role of Counsel in Mental Disability Cases, 16 LAW \& HUM. BEHAV. 39, 57 n. 115 (1992)).

229. Terry Maroney, Emotional Regulation and Judicial Behavior, 99 CAL. L. REV. 1485, 1492 (2011). 
judges to focus on information that confirms their preconceptions (i.e., confirmation bias), to recall vivid and emotionally charged aspects of cases (i.e., the availability heuristic), and to interpret information that reinforces the status quo as legitimate (i.e., system justification biases). ${ }^{230}$

How does this play out in the context of sex offenders? Writing about how mental disability is perceived in the legal profession, one of the authors (MLP) has said:

Judges and jurors, both consciously and unconsciously, often rely on reductionist, prejudice-driven stereotypes in their decision-making, thus subordinating statutory and case law standards as well as the legitimate interests of the mentally disabled persons who are the subject of the litigation. Judges' predispositions to employ the same sorts of heuristics as do expert witnesses further contaminate the process. $^{231}$

We believe that the same sort of "contaminat[ion]"232 takes place in the sex-offender arena as well.

\section{A FUTURE DESIGNED THROUGH KNOWLEDGE, THERAPEUTIC JURISPRUDENCE, AND THE UNIVERSAL APPLICATION OF HUMAN DIGNITY AND RIGHTS}

Eight years ago, Dr. Astrid Birgden suggested that therapeutic jurisprudence, with its emphasis on increasing therapeutic effects and decreasing anti-therapeutic consequences of the law, might provide the necessary framework to ensure community and offender protection. ${ }^{233} \mathrm{Her}$ suggestions to create an effective system focused on the collaboration of efforts between legal practitioners, correctional practitioners and the court system..$^{234}$ A psycho-legal approach can be successful in addressing sexoffender assessment (risk and need principles), treatment (need and internal responsivity principles), and management (external responsivity principles) so long as the focus rests on both community and offender protection. ${ }^{235}$ In

230. Eden B. King, Discrimination in the 21st Century: Are Science and the Law Aligned?, 17 PSychol. PuB. PoL'Y \& L. 54, 58 (2011) (citing Charles G. Lord et al., Biased Assimilation and Attitude Polarization: The Effects of Prior Theories on Subsequently Considered Evidence, $37 \mathrm{~J}$. Personality \& SoC. Psychol. 2098 (1979); Amos Tversky \& Daniel Kahneman, Availability: $\boldsymbol{A}$ Heuristic for Judging Frequency and Probability, 5 CoGNITIVE PSYCHOL. 207 (1973); John T. Jost \& Mahzarin R. Banaji, The Role of Stereotyping in System-Justification and the Production of False Consciousness, 33 BRIT. J. SOC. PSYCHOL. 1 (1994)).

231. Michael L. Perlin, "Baby, Look Inside Your Mirror": The Legal Profession's Willful and Sanist Blindness to Lawyers with Mental Disabilities, 69 U. PITT. L. REV. 589, 602-03 (2008).

232. Id.

233. Birgden, supra note 207 , at 362 .

234. Id. at 359.

235. Id. at 353. 
the courtroom setting, correctional practitioners can advise the court on offender rehabilitation techniques (offender protection) while legal practitioners maintain an environment that assists offenders in engaging in treatment (community protection). ${ }^{236}$ In the corrections setting, legal practitioners can provide advice on ethical treatment (offender protection) while correctional practitioners can increase the courts' confidence in rehabilitation (community protection). ${ }^{237}$

Clearly, we must focus our efforts and resources on reintegration into society, rather than removal and alienation. Sex-offender civil commitment is not going by the wayside, and, following the recent Supreme Court decision upholding federal civil commitment in United States $v$. Comstock, ${ }^{238}$ it may gain more support. ${ }^{239}$ Given the limited effectiveness and knowledge of treatment combined with the lengthy and indefinite time spent in sex-offender civil commitment, ${ }^{240}$ states should re-allot their resources and focus on fostering rehabilitation and reintegration into the community. If we continue to support civil commitment under the guise of treatment and the hope that individuals can be treated, then ethically, we must tailor treatment to assist in re-entering society. ${ }^{241}$ Focus should follow TJ ideals and aim to promote sex offenders' self-respect and dignity, while teaching these individuals to engage in emotionally intimate relationships with others. ${ }^{242}$ Preparation for release should include job training, education and life skills. ${ }^{243}$ We must support the transition back into the community by

236. Birgden, supra note 207, at 357-58.

237. Bill Glaser, Treaters or Punishers? The Ethical Role of Mental Health Clinicians in Sex Offender Programs, 14 AGGRESSION \& VIOLENT BEHAV. 248, 250 (2009).

238. 130 S. Ct. 1949, 1961 (2010)(finding that Congress has the authority to create federal civil commitment legislation under the Necessary and Proper Clause because it is a "federal custodian" with "the constitutional power to act in order to protect nearby (and other) communities from the danger federal prisoners may pose").

239. Brief for the States of Kansas et al, as Amici Curiae in Support of Petioners at 1, United States. v. Comstock, 130 S. Ct. 1949 (2010) (No. 08-1224), 2009 WL 2896311 (explaining that in 1990 only one state had enacted sex offender commitment laws but by 2010 at least 21 states had such laws).

240. Eric S. Janus, The Preventative State, Terrorists, and Sexual Predators: Countering the Threat of a New Outsider Jurisprudence, 40 CRIM. L. BULL. 576, 580-81 (2004).

241. Wakefield, supra note 4, at 146 ("The SVP laws were passed with the promise of rehabilitation as a major goal. Confinement would be limited because treatment would be provided and the 'patients' would be released as soon as they were no longer dangerous or mentally disordered. But in reality, committed sex offenders are rarely discharged. The primary purpose of these laws is incapacitation-to prevent future sexual violence by direct physical constraint. Treatment is only an additional purpose. In reality, punishment, isolation, and incapacitation are the dominant purposes. La Fond [sic] observes that in some states, there was no bona fide treatment program in place when the individuals were committed.") (citations omitted); see also John Q. La Fond, The Future of Involuntary Civil Commitment in the U.S.A. after Kansas v. Hendricks, 18 BEHAV. SCI. \& L. 153, 163 (2000) (discussing the need for treatment programs to serve a therapeutic purpose).

242. See Prentky \& Schwartz, supra note 54, at 10 ("The most important point, however, is that the overarching goal of reducing sexual violence in society must rest squarely with the forces within society that promote and foster sexual violence. By merely reducing the risk of those who have already tumed to sexual violence, we will never achieve the ultimate aim of making society a safer place by restoring the rights to sexual autonomy for women and children.") (emphasis added).

243. See Kathryn C. Sammon, Therapeutic Jurisprudence: An Examination of Problem-Solving Justice in New York, 23 ST. JouN's J. C.R. \& F.CON. DEV. 923, 926 (2008) (noting that problem-solving 
fostering family and community relationships.

Certainly, the authors are not so naïve as to believe that this will benefit every type of person who commits sexual offenses; rather, we conclude that the suggestions offered here, for reintegration, must be the main focus and starting point of any coherent policy, in order to maximize success.

Residency restrictions should be completely dismantled due to their anti-therapeutic effect and unfounded ability to have any impact on diminishing re-offense and making communities safer. If we choose to continue still have some form of community monitoring, it must be done through an individualized assessment of risk, likelihood, and danger based on credible, peer-reviewed studies and ethical evaluations. We should encourage and reward efforts to engage in community service and acknowledge former offenders' genuine attempts to live offense-free and contribute to society. To quote the late Professor Bruce Winick, "[m]odernday sex offenders should also be offered the possibility of redemption." ${ }^{44}$ "Feel-good" legislation should be abolished insofar as it serves no other purpose but to humiliate, label, and dehumanize the individual.

In the courtroom context, we need to think more seriously about the role of problem-solving courts in dealing with this phenomenon and how, if properly conceived of and conducted, such courts can be the best assurance that $\mathrm{TJ}$ will be an important and integral part of the decision-making process. ${ }^{245} \mathrm{TJ}$ can potentially re-educate judges to aid them in "identify[ing] alternatives to harsh punishments ... particularly since the punitive response often leads to recidivism in most cases." 246

$\mathrm{TJ}$ instructs us to step back from myths and prevailing attitudes and to carefully consider the prescriptions of therapeutic jurisprudence principles. ${ }^{247}$ Recall the "three Vs"-voice, validation and voluntary participation-that Professor Amy Ronner has discussed. ${ }^{248}$ The current sex-offender laws honor none of these prescriptions. It is time we seriously re-evaluated them all. We must educate ourselves, confront our fears, and resist the urge to succumb to reactionary responses. These emotionally charged issues must be dealt with through rational solutions directed

courts employing TJ seek to increase availability of job training, adult education, and anger management in keeping with therapeutic jurisprudence principles).

244. Winick, supra note 13, at 567.

245. See, e.g., Emily Horowitz, Growing Media and Legal Attention to Sex Offenders: More Safety or More Injustice?, J. INST. JUST. \& INT'L STUD. 143, 154 (2007) ("[A]lternative policy options include specialized sex offender re-entry courts, which can evaluate risk, manage treatment, and closely monitor sex offenders upon release. These courts are significantly cheaper than inpatient psychiatric facilities.") (citations omitted); see also, La Fond \& Winick, supra note 212, at 1174 (noting that sex-offender courts-which are based on $\mathrm{TJ}$ principles--offer improved community protection and sex-offender rehabilitation over traditional methods).

246. Brian G. Sellers \& Bruce A. Arrigo, Adolescent Transfer, Developmental Maturity, and Adjudicative Competence: An Ethical and Justice Policy Inquiry, 99 J. CRIM. L. \& CRIMINOLOGY 435, 480 (2009).

247. Birgden, supra note 207, at 354; Birgden \& Cucolo, supra note 59, at 306; Winick, supra note 13, at 507-08.

248. Ronner, supra note 196, at 94-95. 
towards protecting potential victims while preserving the human rights of all. ${ }^{249}$

249. HUMAN RIGHTS WATCH, supra note 91 , at 12 ("Reforming sex offender laws will not be easy. At a time when national polls indicate that Americans fear sex offenders more than terrorists, legislators will have to show they have the intelligence and courage to create a society that is safe yet still protects the human rights of everyone."). 